\title{
Non-canonical dimerization of the androgen receptor and other nuclear receptors: Implications for human disease
}

3

Alba Jiménez-Panizo1, Paloma Pérez², Ana Rojas ${ }^{3}$, Pablo Fuentes-Prior ${ }^{4 \#}$, and

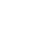
Eva Estébanez-Perpiñá1\#

1Department of Biochemistry and Molecular Biomedicine. Institute of Biomedicine (IBUB) of the University of Barcelona (UB), 08028 Barcelona, Spain.

2Instituto de Biomedicina de Valencia (IBV)-CSIC, Valencia, Spain

${ }^{3}$ Computational Biology and Bioinformatics Group. Andalusian Center for Developmental Biology (CABD-CSIC). Crta. de Utrera S/N. Campus Universitario Pablo de Olavide. 41013, Sevilla

${ }^{4}$ Molecular Bases of Disease, Biomedical Research Institute Sant Pau (IIB Sant Pau), 08025 Barcelona, Spain.

\section{\#Corresponding authors:}

Eva Estébanez-Perpiñá. E-mail: evaestebanez@ub.edu

Pablo Fuentes-Prior. E-mail: pfuentes@santpau.cat

Keywords: androgen receptor, glucocorticoid receptor, protein structure, ligand binding domain, multimerization, prostate cancer, androgen insensitivity syndromes (AIS), hormone resistance 


\section{Abstract}

Nuclear receptors are transcription factors that play critical roles in development, homeostasis and metabolism in all multicellular organisms. An important family of nuclear receptors comprises those members that respond to steroid hormones, and which is subdivided in turn into estrogen receptor (ER) isoforms $\alpha$ and $\beta$ (NR3A1 and A2, respectively), and a second subfamily of so called oxosteroid receptors. The latter includes the androgen receptor (AR/NR3C4), the glucocorticoid receptor (GR/NR3C1), the mineralocorticoid receptor (MR/NR3C2), and the progesterone receptor (PR/NR3C3). Here we review recent advances in our understanding of the structure-and-function relationship of steroid nuclear receptors, and discuss their implications for the etiology of human diseases. We focus in particular on the role played by AR dysregulation in both prostate cancer (PCa) and androgen insensitivity syndromes (AIS), but also discuss conditions linked to mutations of the GR gene as well as those in a non-steroidal receptor, the thyroid hormone receptor (TR). Finally, we explore how these recent results might be exploited for the development of novel and selective therapeutic strategies. 


\section{Introduction}

Nuclear receptors (NRs) form a superfamily of related transcription factors that play essential roles in multicellular organisms through coordination of pivotal signaling networks (Evans and Mangelsdorf 2014). One important family of NRs groups together those members that respond to steroid hormones, accordingly termed steroid family. In vertebrates, the steroid NRs include estrogen receptor (ER) isoforms ER $\alpha(N R 3 A 1)$ and $E R \beta$ (NR3A2) together with the androgen receptor (AR/NR3C4), the glucocorticoid receptor (GR/NR3C1), the mineralocorticoid receptor (MR/NR3C2), and the progesterone receptor (PR/NR3C3). Phylogenetic studies show that AR, GR, MR and PR comprise a subfamily of so called oxosteroid NRs, which markedly differ from both ER isoforms (Bledsoe et al. 2002, Evans and Mangelsdorf 2014, Gallastegui et al. 2015, Zennaro and Fernandes-Rosa 2017, Katzenellenbogen et al. 2018). This phylogenetic separation is also reflected at the level of tertiary and quaternary structures, as we will discuss below.

We note that some members of other subfamilies of NRs specifically respond to steroid hormones, for instance the vitamin D3 receptor (VDR/NR1/1), the bile acid receptor (FXR/NR1H4), oxysterol receptors $\alpha$ and $\beta$ (LXR $\alpha / \mathrm{NR} 1 \mathrm{H} 3$ and $L X R \beta / N R 1 H 2$, respectively) and the retinoid-related orphan receptors $\alpha, \beta$ and $\gamma($ ROR $\alpha / N R 1 F 1$, ROR $\beta / N R 1 F 2$, and ROR $\gamma / N R 1 F 3$, respectively). However, for space reasons we will focus in the current review almost exclusively on the members of the sequence and structurally related "classical" steroid family of NRs, most notably on the AR. 
Similar to other NRs, the members of the steroid family display a marked modular structure: a variable $\mathrm{N}$-terminal region called the $\mathrm{N}$-terminal domain (NTD) is followed by a highly conserved DNA-binding domain (DBD) comprised of two zinc finger motifs, and a C-terminal ligand-binding domain (LBD) that contains the internal ligand-binding pocket (LBP) (Jenster et al. 1995, McEwan 2012a, Gallastegui et al. 2015, Tien and Sadar 2018, Weikum et al. 2018, Fuentes-Prior et al. 2019, Veras Ribeiro Filho et al. 2019). DBD and LBD modules are separated by a poorly conserved interdomain linker called 'hinge', which harbors a nuclear localization signal (NLS). (See Fig. 1 for a schematic representation of the domain organization in steroid NRs). All the NR-comprising domains are proposed drug targets, but the LBD remains still the main module for therapeutic intervention and, in spite of intense efforts, no molecule targeting other receptor domains has advanced into late clinical trials (Sadar 2011, Dalal et al. 2014, Nadal et al. 2017, Veras Ribeiro Filho et al. 2019). Over the years, several physiologically relevant protein partners of NRs have been reported to selectively fine-tune their actions in various tissues. These factors, collectively termed coregulators, can either enhance or inhibit transcription of target genes, and are therefore known as coactivators or corepressors, respectively (Hermanson et al. 2002, Perissi and Rosenfeld 2005, Dasgupta et al. 2014). These NR coregulators underlie the tissue-selective actions of NR ligands and are also emerging therapeutic targets per se, although they have proved hard to target so far (Yi et al. 2015, Wang et al. 2016, Ruggero et al. 2018). All NR domains have been involved in coregulator recruitment and macromolecular complex formation, although the atomic details still remain elusive (Dasgupta et al. 2014, Foley and Mitsiades 2016, Giudici et al. 2016, Lempiäinen et al. 2017). 
Although the NTDs are variable in length and intrinsically disordered (i.e., isolated NTDs lack stable secondary (2D) and/or tertiary (3D) structures under physiological conditions), the results of different biochemical and biophysical studies suggest that they undergo at least partial folding ("helicity induction") to modulate the formation of competent transcription activation complexes around the NRs (Kumar et al. 2004, McEwan et al. 2007, De Mol et al. 2016, De Mol et al. 2018). This is particularly relevant for a polypeptide stretch termed activation function-1 (AF-1; residues 142-485 in the human AR), which is a hormoneindependent transactivation function (Fig. 1). An important result of early investigations on the role of the NTD was the realization of at least transient contacts with the C-terminal LBD moiety. These intra- or intermolecular amino/carboxy terminal $(\mathrm{N}-\mathrm{C})$ interactions play key roles in regulating the functions of some steroid receptors, both by stabilizing the overall protein structure and by modulating interactions with DNA and coregulators, thus ultimately controlling gene expression (Langley et al. 1998, He and Wilson 2002, Bai et al. 2005). On the LBD, a solvent-exposed pocket responsible for recognizing both AF-1 and coregulators has been extensively studied, which is called activation function 2 (AF-2) or ligand-dependent coactivator-binding site pocket that contributes to allosterically regulate receptor functions, and which has been termed binding function-3 (BF-3) (Estébanez-Perpiñá et al. 2005, 
111 Estébanez-Perpiñá et al. 2007b, Buzón et al. 2012, Ravindranathan et al. 2013,

112 Badders et al. 2018). ${ }^{1}$ (Fig. 2B)

In the following section, we will briefly discuss recently presented results on the structure-and-function relationship of the AR, but will refer to and compare with other steroid NRs when appropriate.

The "life cycle" of the androgen receptor - From chaperone-bound monomer to multimers on chromatin

Newly synthesized AR is present in the cytoplasm associated with major molecular chaperones (Prescott and Coetzee 2006, Centenera et al. 2013a, Guy et al. 2015, Foley and Mitsiades 2016, Kita et al. 2017). AR first binds to the heat shock protein 70 (Hsp70)-Hsp40 complex, which is followed by binding of Hsp90 and co-chaperones and subsequent dissociation of Hsp70-Hsp40. Hsp90 binding ensures that the AR retains a high-affinity conformation for the androgenic hormones, testosterone and its more potent derivative, dihydrotestosterone (DHT) (Hernández et al. 2002, Azad et al. 2015). Another chaperone, Hsp27, is regulated by cell stress and prevents aggregation and degradation of the $A R$, besides promoting nuclear trafficking of the receptor and its binding to DNA (Zoubeidi et al. 2007). chaperone complex, likely accompanied by significant conformational changes, nuclear translocation of the receptor and its dimerization, which is a critical step

\footnotetext{
${ }^{1}$ A note of caution must be added here, as most of the structural and functional evidence comes from studies performed using short peptides derived from known coregulators, which might not correctly reproduce interactions found in multiprotein complexes in vivo.
} 
132 within this signaling pathway (Centenera et al. 2008, van Royen et al. 2012, Nadal et al. 2017). Pioneer studies suggested that AR oligomerization precedes binding to chromatin, and demonstrated that DNA binding was redox-dependent (Kokontis and Liao 1998). More recently, AR dimerization has been shown to enhance chromatin interaction and remodeling to modulate gene expression (Jin et al. 2013). However, it must be stressed that the exact cycle of AR monomerto-oligomer transition in the cell has not been precisely elucidated (Schaufele et al. 2005, Centenera et al. 2008, van Royen et al. 2012, Nadal et al. 2017). It is usually assumed that this transition follows exactly the same steps as in related NRs, although data supporting this assumption is incomplete, or simply lacking.

Recent studies of steroid NR trafficking in living cells have dramatically advanced our understanding of this process, forcing a paradigm shift in the field. In particular, careful quantitation of $G R, A R$ and PR dynamics at the singlemolecule level have unexpectedly revealed that the dimeric forms of these al. 2019). 


\section{Quaternary structure of the AR-LBD: Functional implications}

158 Several AR features have complicated elucidation of the physiologically relevant tertiary and quaternary structures of full-length AR (FL-AR) and other steroid receptors, and it is still a matter of debate e.g. whether the biological units are dimers or 'dimers of dimers' (see above and refs. (Presman et al. 2016, Nadal et al. 2017, Presman et al. 2017, Presman and Hager 2017)). In addition to the conformational flexibility that is a prerequisite for the functional versatility of the individual AR modules, they are known to interact with each other to precisely regulate the NR functions in a context-dependent manner. Further, it is worth noting that post-translational modifications (PTMs) profoundly modulate AR actions, both under physiological and pathological conditions (Faus and Haendler 2013, Koryakina et al. 2014). The intrinsically disordered nature of the long NTD and its unique interactions with the LBD (the 'N/C contacts') raised over the years the issue of whether FL-AR dimerizes in a parallel, "head-to-head" manner, or alternatively in an anti-parallel, "head-to-tail" configuration (Langley et al. 1995, Langley et al. 1998, Schaufele et al. 2005, Centenera et al. 2008, Minges et al. 2013). On the other hand, the crystal structure of rat AR-DBD revealed a head-to-head homodimer bound to its cognate DNA (Shaffer et al. 2004), in an arrangement quite similar to that adopted by DBD dimers of GR (Luisi et al. 1991) and ER 178 (Schwabe et al. 1993). In this conformation, the C-terminal residues of both monomers, corresponding to L627 in the human receptor, are located far away (about $50 \AA$ A). However, the length of the G628-E669 linker does not allow for an accurate prediction of the likely arrangement of LBD monomers in a hypothetical 
182 dimer. In fact, limited and contradictory information in support of AR-LBD dimerization had been presented over the years, with some authors even suggesting that the LBD-LBD interactions may not significantly contribute to receptor oligomerization (Schaufele et al. 2005, Centenera et al. 2008, van Royen et al. 2012, Nadal et al. 2017).

The long standing questions of whether the AR-LBD domain dimerized and the relative arrangement of monomers have been answered with the resolution of the crystal structure of human AR-LBD bound to DHT and a peptide derived from the coregulator, ubiquitin-activating enzyme 3 (UBA3) (Nadal et al. 2017). All the AR-LBD structures previously solved by us and others had captured essentially the same conformation of monomeric AR-LBD (Matias et al. 2000, Sack et al. 2001, He et al. 2004, Estébanez-Perpiñá et al. 2005, Bohl et al. 2007, Estebanez-Perpina et al. 2007). In striking contrast, our recent crystal structure features four independent, helically arranged LBD molecules (Nadal et al. 2017) (Fig. 2B). Two of these LBD monomers are arranged in a symmetrical 'core dimer', while the other two peripheral partners are associated in a less compact manner to the BF-3 sites of each of these monomers (Fig. 2B). The core AR-LBD dimer exhibits a head-to-head arrangement and displays the corresponding coactivator binding sites (AF-2 pockets) facing opposite directions, thus able to independently interact with coregulators (Fig. 2A).

Helices 5 (H5) from both AR-LBD moieties occupy the center of the dimerization interface (Fig. $3 A$ ), which is thus topologically distinct from the 'canonical', H10-11-centered arrangements identified, among others, in ER homodimers and in RXR-mediated heterodimers (Fig. 3C) (Wurtz et al. 1996, Brzozowski et al. 1997, Bourguet et al. 2000, Chandra et al. 2008, 
207 Khorasanizadeh and Rastinejad 2016, Chandra et al. 2017, Nadal et al. 2017,

208 Fuentes-Prior et al. 2019). The H5-centered dimerization mode of human AR-

209 LBD has been confirmed in solution and in cells (Nadal et al. 2017). This noncanonical dimeric conformation might be shared by other NRs, not only of the oxosteroid class (Fuentes-Prior et al. 2019). In fact, a topologically equivalent dimer of GR-LBD had been previously reported (Bledsoe et al. 2002) (Fig. 3B), although its biological relevance has been questioned upon careful comparison of currently available GR structures, and alternative GR dimeric conformations have been suggested (Bianchetti et al. 2018). Clearly, further experimental work is needed to fully clarify the physiologically relevant conformation(s) of the GR and other members of the oxosteroid subfamily to integrate structural, biochemical and cellular studies (Fig. 3) (Bledsoe et al. 2002, Kauppi et al. 2003, Robertson et al. 2013a, Robertson et al. 2013b, Presman et al. 2016, Paakinaho et al. 2017, Presman et al. 2017, Presman and Hager 2017, Weikum et al. 2017, Wilkinson et al. 2018).

Although specific functions have been commonly ascribed to the different NR domains (e.g., DNA and hormone binding), seminal X-ray crystallography studies of non-steroidal NRs indicate that DBD, hinge and LBD are more intricately interconnected than initially thought, both structurally and functionally ((Chandra et al. 2008, Chandra et al. 2013, Lou et al. 2014, Chandra et al. 2017), reviewed in (Rastinejad et al. 2015, Fuentes-Prior et al. 2019)). Regarding the AR and other steroid receptors, current knowledge of their inter-domain interactions derives mostly from biochemical and mutagenesis studies. A recent analysis of multidomain ER by small-angle X-ray scattering (SAXS), however, suggests an important cross-talk between DBD and LBD moieties (Huang et al. 
2018). These findings, at the light of the results of Rastinejad and coworkers with non-steroidal NRs, point to important DBD-linker-LBD interactions in vivo ((Chandra et al. 2008, Chandra et al. 2013, Chandra et al. 2017), reviewed in (Fuentes-Prior et al. 2019)). This is in addition to the well-known intra- or intermolecular N-C interactions (see above), which restrict the possible DBD/LBD relative orientations (Fig. 4B).

\section{Allosteric modulation of AR activity}

NRs are allosteric proteins par excellence (Kuriyan 2004, del Sol et al. 2006, McEwan 2012b, Mackinnon et al. 2014), and the AR is no exception in this regard (Estebanez-Perpina et al. 2007, Buzón et al. 2012, Grosdidier et al. 2012). Indeed, FL-AR functions as an allosteric switch alternating between inactive, chaperone-bound / ligand-free states, and active, hormone- and coactivatorbound conformations. Ligand binding and the exchange of chaperones by coactivators are allosterically coupled, but the sequence of molecular events and detailed conformational changes associated are only partially understood (Hur et al. 2004, Estébanez-Perpiñá et al. 2005). In particular, hormone binding to the LBP has been shown to trigger allosteric remodeling of the AF-2 and BF-3 interaction surfaces. In this manner, occupancy of the LBP by ligands regulates the dynamics and stability of surfaces that recognize coregulators, and is thus allosterically coupled to the recruitment of these proteins to the AR (EstébanezPerpiñá et al. 2005, Estebanez-Perpina et al. 2007). Albeit a recent proteomics study have identified the essentially overlapping, agonist-specific interactomes of both AR and GR (Lempiäinen et al. 2017), the detailed molecular determinants of NR binding to a large number of coregulators are far from being well understood. 
Noteworthy, in addition to allosteric rearrangements elicited by hormone binding, the target DNA sequences to which NRs bind also induce important remodeling of the receptor structure (Fuentes-Prior et al. 2019). Most impressively, cognate DNA binding sequences of the GR have been shown to function as true allosteric modulators, which are capable of affecting conformation and regulate receptor activity (Meijsing et al. 2009, Love et al. 2017, Weikum et al. 2017, Frank et al. 2018). Thus, a change in a single base pair in the GR binding site resulted in up to 10 -fold higher affinity in the activation of a glucocorticoid response element (GRE) reporter gene in response to ligand. More recently, it has been reported that nucleotides directly flanking the core-binding site not only modulate the 3D structure of this site, but also that of the GR-DBD, and even the quaternary conformation of the dimeric receptor (Schöne et al. 2016). This implies that GR activity can be modulated by both sequence composition and DNA shape to achieve fine-tuning of the GR structure and activity downstream of binding. These features are likely to be shared by other members of the oxosteroid class of NRs, at the light of the almost identical sequences of DBDs and relative conservation of interdomain hinges. This flanking effect could explain how NRs predicted to recognize similar binding motifs show distinct DNA-binding preferences in vivo. It is feasible that while two related NRs can bind to the same DNA motif, the competent conformation required for an optimal transcriptional response is only achieved through specific flanking sequences. In particular, we assume that AR-DBD binding to its cognate DNA sequences will trigger intra- and interdomain conformational changes that would affect the overall quaternary structure of the receptor, including its hormone-binding domain. 

The precise molecular mechanisms underlying allosteric transitions in FL$A R$, including the equilibrium between different conformational states and the impact of ligand binding to allosteric modulatory sites (e.g., AF-2, BF-3) on receptor oligomerization, remain to be worked out (Fig. 2A) (Nadal et al. 2017). In multi-domain AR, both intra- and inter-domain allostery may occur simultaneously (Fernandez et al. 2017, Fernandez 2018). The first may take place within either the NTD, DBD or LBD moieties, while inter-domain signal transduction appears to be essential in coordinating AR functions (e.g., through the well-studied N-C contacts, but also upon as of yet uncharacterized DBD-LBD and LBD-DNA interactions). Similar considerations might apply to other steroid NRs.

\section{Dysregulation of steroid receptors and human disease}

Given the essential roles of steroid hormones and their cognate NRs in development, homeostasis and metabolism, it is not surprising that dysregulation of their activities is directly responsible for a number of important human conditions (Huang et al. 2010, Evans and Mangelsdorf 2014, Luo et al. 2018). most conspicuous association between a nuclear receptor and human disease links the AR to several biomedical conditions, as we briefly discuss below. 
Genetic bases of drug resistance in prostate cancer

AR is encoded by a ubiquitously expressed gene located in the X-chromosome at Xq11-12, and is particularly important in prostate development and homeostasis (Lubahn et al. 1988). When dysregulated, however, AR activity is central to the onset, development, and progression to metastasis of prostate cancer (PCa), the most common cancer diagnosed in males worldwide (Matias et al. 2000, Gottlieb et al. 2004, Knudsen and Penning 2010, Arora and Barbieri 2018, Centenera et al. 2018, Cioni et al. 2018, Li et al. 2018, Luo et al. 2018, Nevedomskaya et al. 2018, Paschalis et al. 2018). In addition, AR mutations are linked to disorders of male sexual differentiation and development termed androgen insensitivity syndromes (AIS) (Hughes et al. 2012, Mongan et al. 2015, Gibson et al. 2018), and to the rare adult-onset hereditary neurodegenerative disorder known as spinal and bulbar muscular atrophy (SBMA or Kennedy's disease; OMIM \#313200) (Spada et al. 1991, Badders et al. 2018, Cortes and La Spada 2018, Lieberman 2018, Pennuto and Rinaldi 2018). Finally, AR malfunction is also associated to androgenic alopecia or loss of scalp hair and skin malignancies (Ellis et al. 2001, Clocchiatti et al. 2018).

Several altered genetic and epigenetic mechanisms contribute to the development of metastatic and drug-resistant PCa (Knudsen and Penning 2010, Shen and Abate-Shen 2010, Grasso et al. 2012, Robinson et al. 2015, Pritchard et al. 2016, Baumgart and Haendler 2017, Armenia et al. 2018, Cotter and Rubin 2018, Karthaus and Sawyers 2018, Li et al. 2018, Quigley et al. 2018, Ruggero et al. 2018). For example, tandem duplications of an upstream enhancer of the $A R$ are found in up to $87 \%$ of metastatic castration-resistant $\mathrm{PCa}$ (mCRPC) cases, compared to $<2 \%$ of primary prostate cancers (Takeda et al. 2018, 
332 Viswanathan et al. 2018, Wu et al. 2018). In addition, it has been recently reported that deletion of the gene encoding the chromatin remodeler, chromatin helicase DNA-binding protein (CHD1), redistributes the AR cistrome in a manner that favors expression of PCa-specific oncogenic pathways (Augello et al. 2019).

Not surprisingly, CHD1 loss had been previously reported as one of the most common and deleterious genetic alterations in PCa (Grasso et al. 2012, Huang et al. 2012, Rodrigues et al. 2015, Zhao et al. 2017) and an early event in cancer development (Wedge et al. 2018).

Further, $A R$ gene duplications and AR-mediated chromosomal rearrangements are common events. Among them, about half of the patients with PCa feature fusions of the AR-regulated gene, TMPRSS2, with different fragments of the ETS-related gene (ERG), a member of the ETS family of transcription factors. The presence of these TMPRSS2:ERG fusions defines the predominant molecular subtype of PCa (Yu et al. 2010, Park et al. 2014, Reig et al. 2016, Berglund et al. 2018, Stelloo et al. 2018). The encoded ERG truncated variants are resistant to degradation and transform the AR from a factor promoting lineage-specific differentiation of the prostate to one that potentiates de-differentiation into a stem cell-like state (Yu et al. 2010). However, TMPRSS2:ERG fusions alone do not appear to be transforming (Casey et al. 2012), and the precise mechanism(s) by which they contribute to PCa initiation and/or progression are still a matter of debate. For instance, it has been reported that these fusions synergize with deletion of the tumor suppressor, PTEN, to promote prostatic intraepithelial neoplasia (PIN) (Carver et al. 2009, King et al. 2009, Casey et al. 2012). In this regard, and also connecting to the work by Augello and coworkers cited above, it has been proposed that ETS factors alter 
357 the AR cistrome to prime the prostate epithelium to respond to aberrant signals such as PTEN loss, thus ultimately resulting in prostate-specific transformation (Chen et al. 2013). Carver and coworkers also observed that two genes strongly associated with cell migration, ADAMTS1 and CXCR4, were upregulated upon ERG overexpression (Carver et al. 2009). Besides, overexpression of MMP9 and plexin B correlates with the presence of the fusion in samples of PCa patients, and has been linked to migration and invasion of prostate cancer cells (Liu et al. 2017).

On the other hand, several studies have described the synthesis in vivo of alternatively spliced transcripts encoding truncated AR isoforms. The identification of these constitutively active $A R$ variants (AR-Vs), which lack portions or the entire hormone-sensitive LBD, has added an unanticipated level of complexity to the AR signaling pathways (Dehm and Tindall 2011, Centenera et al. 2013b, Ho and Dehm 2017). Many of these truncated AR-Vs seem to support androgen-independent expression of AR-target genes, and therefore androgen-independent growth of PCa cells (Dehm and Tindall 2011). However, the androgen-independency of $A R-V s$ does not imply that expressing cells are totally independent of the presence of androgenic hormones. The (patho)physiological implications of the coexistence of full-length AR with one or several AR-Vs in the same cell are still a matter of intense debate. The likely formation of AR-Vs (hetero)dimers with FL-AR, either through DBD-mediated or $\mathrm{N}-\mathrm{C}$ interactions may still result in hormone-dependent cell growth leading to PCa progression (Liu et al. 2014, Uo et al. 2017). Further, potential differences in the interactomes of the different $A R-V s$ in comparison with that of the full-length receptor have not been explored so far. 


\section{The AR-LBD dimerization interface is a hot spot of disease-linked mutations} Inspection of the 3D structure of the AR-LBD homodimer immediately revealed that a large number of hitherto unexplained mutations of solvent-exposed residues identified in PCa (Fig. 5A) and AIS patients cluster at the dimerization interface ((Nadal et al. 2017); see also Fig. 5B). We stress that these mutations might have additional consequences for AR protein structure and function, such as impaired interaction with chaperones in the monomeric state (see above). Accordingly, the situation in vivo does not fit a simplistic dichotomy of gain-offunction mutations causing $\mathrm{PCa}$, while loss-of-function variants of the $A R$ gene are linked to AIS (Hay and McEwan 2012).

Nevertheless, there are several correlations between e.g. the nature of the mutant residue and disease severity, which strongly point to impaired homodimer formation as more likely cause of the observed phenotype. This is in particular the case of repeatedly identified mutations that affect residues such as F755, N757, V758, N759, R761, and P767 (Fig. 4A, Fig. 5A and 5C). Most notably, the mutant $\mathrm{Y} 764 \mathrm{C}$, which has been found both in PCa and AIS, and residue F755 that has been found conservatively replaced by either leucine, in some patients with partial AIS, or by another aliphatic residue, valine, in cases of complete androgen insensitivity. The side chain of F755 makes important Van der Waals interactions with P802 from the second monomer (Fig. 4A), and modeling experiments indicate that a leucine residue at position 755 might still interact with this proline, supporting homodimer formation. However, a less bulky valine would not be able to contact P802, with concomitantly impaired dimerization. A second example of strong genotype-phenotype correlation is given by mutant p.V758I identified in PCa patients. Again, a fully conservative replacement of an aliphatic 
407 residue leading to PCa is most likely reflects the higher stability of the homodimer

408 formed by mutant AR-LBD molecules, as the bulkier 1758 side chain fills better

409 the intermonomer space. These findings, among others, lend extraordinary

410 support to the (patho)physiological relevance of the AR homodimer interface, and

411 suggest that this area might be targeted for pharmacological intervention (see

412 below).

NR3C1/GR mutations linked to either glucocorticoid-resistance or hypersensitivity syndromes

Glucocorticoids (GCs) are major regulators of many physiological functions, and thus contribute substantially to tissue homeostasis. Dysfunction of GC-mediated actions underlies two human pathologic conditions, Cushing syndrome and Addison's disease, which are due to GC excess or deficiency, respectively. On the other hand, alterations in GR function (either due to mutations or polymorphisms of the encoding gene, $N R 3 C 1$, or to other molecular changes along the GR signaling pathway) result in impaired tissue-specific sensitivity to GCs, which may manifest as GC resistance or hypersensitivity, both of which are associated with significant morbidity (Nicolaides and Charmandari 2015, Nicolaides et al. 2015a, Nicolaides et al. 2015b, Wilkinson et al. 2018). syndrome, MIM \#615962), NR3C1 heterozygous variants (point mutations, insertions or deletions) result in impaired GR function and thus decreased sensitivity to GCs in all organs, although with a high degree of variability among different tissues . Alterations in the GR function include dysregulation of the GC430 mediated negative feedback mechanisms, which results in compensatory activation of the hypothalamic-pituitary-adrenal (HPA) axis. In turn, HPA 
432 overactivation leads to hypersecretion of ACTH and cortisol (highly variable, ranging from severe symptoms to subclinical hypercortisolism), and may result in 434 increased production of other adrenal steroids such as androgens and mineralocorticoids. Patients affected by this syndrome are thus commonly diagnosed by clinical signs of mineralocorticoid and/or androgen excess (hypertension due to hyperaldosteronism and/or hyperandrogenic signs), rather than those associated with GC deficiency (Kino and Chrousos 2001, Kino et al. 2002, Nicolaides et al. 2010, Charmandari et al. 2013, Nicolaides and Charmandari 2015, Nicolaides et al. 2015a, Nicolaides et al. 2015b, Wilkinson et al. 2018).

So far, 26 mutations have been described in the human NR3C1 gene, most of which are missense mutations and affect the GR-LBD (Vitellius et al. 2016, Nicolaides and Charmandari 2017, Vitellius et al. 2018) (Fig. 5B). Functional studies indicate that most NR3C1 mutations impair several steps of GC signaling including hormone recognition, GR nuclear translocation, DNA binding, and interactions with the coactivator, GRIP1, which ultimately leads to reduced or absent GR-dependent transactivation. Structural studies have contributed to a better understanding of how conformational changes in the receptor cause GC resistance, although a systematic analysis of all reported mutants is lacking. Computer simulations suggest that the primary cause of GC resistance in Chrousos syndrome is an overall destabilization of the LBD, as the result of single amino acid replacements that affect LBP, AF-2, or both (Hurt et al. 2016). The possible role of impaired receptor multimerization on this syndrome, however, has not been explored so far. 
In addition, it has been recently reported that NR3C1 mutations also cause

457

458

459

460

461

462

463

464

465

466

467

468

469

470

471

472

473

474

475

476

477

478

479

another pathological condition called incidentaloma (incidentally discovered bilateral adrenal hyperplasia), with clinical features similar to those of Chrousos syndrome such as asymptomatic hypercortisolism and/or hypertension. Five novel heterozygous $N R 3 C 1$ mutations that cause impaired GR signaling were identified, which represents a relatively high prevalence of $5 \%$ in the analyzed cohort. These findings suggest that the overall prevalence of NR3C1 mutations may have been previously underestimated, and advise to perform GR mutation screening in patients with adrenal incidentalomas (Vitellius et al. 2016, Vitellius et al. 2018). Although most of the identified NR3C1 mutations mapped at the GRLBD, other (p.R477S, p.R477C, p.R477H, and p.Y478C) were located at the Cterminal end of the second zinc finger, implicated in the dimerization of the receptor.

By contrast, in the rare syndrome known as primary generalized glucocorticoid hypersensitivity (PGGH), patients exhibit clinical signs of metabolic syndrome without hypercortisolism, due to compensatory hypoactivation of the HPA axis (Nicolaides and Charmandari 2017). This disease mostly correlates with activating $N R 3 C 1$ polymorphisms while to date, a single patient harboring a point mutation in the NTD (p.D401H) exhibited clinical symptoms of GC hypersensitivity including obesity, type 2 diabetes, and hypertension (Charmandari et al. 2008).

Further, loss-of-function mutations in the NR3C2/MR gene are responsible for renal pseudohypoaldosteronism type 1 (MIM \#177735), a rare disease of mineralocorticoid resistance characterized by sodium and potassium imbalances that manifests at birth with weight loss and dehydration despite elevated plasma 
481 levels of aldosterone. Conversely, an activating MR mutation that reshapes its

482

483

484

485

486

487

488

489

490

491

492

493

494

495

496

497

498

499

500

501

502

503

504

505

LBP (p.S810L) has been associated with a severe form of inherited hypertension (Kino and Chrousos 2001, Zennaro and Fernandes-Rosa 2017). Finally, PR mutations are less frequent but they have been associated to an increased risk of breast, endometrial and colon cancer (Agoulnik et al. 2004).

\section{Impact of mutations affecting the non-canonical dimerization interface in}

\section{other non-steroidal NRs}

We finish this section on the linkage between dysregulation of NR activities and pathologic conditions by presenting the case of a non-steroidal NR that has also been shown to dimerize in an AR-like, non-canonical conformation, the thyroid receptor (TR; refs. (Estébanez-Perpiñá et al. 2007a, Jouravel et al. 2009) and Fig. 5D). Vertebrates possess actually two TR isoforms, termed TR $\alpha$ (NR1A1) and TR $\beta$ (NR1A2), and which are encoded by two independent genes, THRA and $T H R B$, respectively. In spite of their close structural similarity $(70 \%$ sequence identity), these two isoforms differ strongly both in expression profile. TR $\alpha$ is ubiquitously expressed, while TR $\beta$ is mainly expressed in liver, pituitary, inner ear and some brain areas (Chatonnet et al. 2013), but in particular because they regulate different sets of genes. TRs respond to iodinated biomolecules known as thyroid hormones $(\mathrm{TH})$, mostly to the active form 3,3',5-triiodo-L-thyronine (T3), which is generated in turn from the prohormone, L-thyroxine (T4) (Holzer et al. 2017).

Since thyroid hormones have fundamental functions in development, growth and metabolic homeostasis, alterations in TR structure affect these functions at many different levels. This is in particular the case of generalized thyroid hormone resistance (GTHR), a syndrome characterized by elevated 
serum TH but impaired action of these hormones within the hypotalamic-pituitarythyroid axis and variable tissue hyposensitivity to them (Huber et al. 2003a, Huber et al. 2003b, Onigata and Szinnai 2014). GTHR is linked to mutations located in the LBD of TRß (Weiss et al. 1993, Adams et al. 1994). Similar to the results discussed above for GR, most of these mutations result in a lower affinity for T3 or a defective interaction with TR coregulators. Whether are least some of these variants would impair dimer formation has not been experimentally confirmed. However, inspection of the 3D structure of the TR $\beta$ homodimer (EstébanezPerpiñá et al. 2007a, Jouravel et al. 2009) immediately reveals that some of the reported missense mutations actually map to the homodimer interface, and are therefore likely to disrupt receptor homodimerization (Fig. 5D). Particularly interesting mutations in this regard affect arginine residues at positions 320 (p.R320C, p.R320H) and 338 (p.R338W, p.R338L) in TR 3 , as mutations of the topologically equivalent residues in several steroid receptors result in either AIS (p.R753P, p.R753Q in AR), GC resistance (p.R611L in GR) or estrogen insensitivity (p.R394H in ER) (see Table 1) (Weiss et al. 1993).

In summary, residues responsible for non-canonical homodimer formation in NRs play a critical functional role, leading to various pathological conditions when dimerization is disrupted. A list of mutations that are likely to interfere with non-canonical homodimer formation of some NRs and their associated conditions is given in Table 1.

\section{Implications for the development of novel therapeutic strategies}

All steroid NRs are major therapeutic targets to treat several endocrine-related diseases (Moore et al. 2006, Evans and Mangelsdorf 2014, Carroll 2016, Nasrazadani et al. 2018). Most notably, the dependence of PCa tumors on the 
531 AR protein and its cognate endogenous hormones is the basis for its pharmacological exploitation as drug target. Indeed, inhibition of AR functions by means of ligand depletion and/or the use of AR antagonists (antiandrogens) is the first line of therapeutic intervention against PCa (Chen et al. 2008, Mohler et al. 2012, Lorente et al. 2015, Aggarwal et al. 2017, Ponnusamy et al. 2017, Narayanan et al. 2018, Nevedomskaya et al. 2018). However, recurrent resistant and incurable tumors arise as a result of inappropriately restored AR function associated with various genetic and epigenetic accidents. In particular, emergence of point mutations as a response to antiandrogen therapy is a quite common event, which may result in antiandrogens acting as agonists rather than antagonists with severe clinical consequences (Knudsen and Penning 2010, Balbas et al. 2013, Joseph et al. 2013, Schrecengost and Knudsen 2013, Lorente et al. 2015, Watson et al. 2015, Jernberg et al. 2017, Giacinti et al. 2018). The identification of constitutively active, truncated splice AR variants (AR-Vs) lacking parts or the entire LBD also poses important pharmacological challenges (Dehm and Tindall 2011, Centenera et al. 2013b, Ho and Dehm 2017, Paschalis et al. 2018). This is in addition to the cross-reactivity of therapeutic steroidal androgens with other, highly related steroid NRs (i.e., GR) in PCa patients, which derives in unwanted side effects that pose additional limits to their clinical use (Arora et al. 2013, Karamouzis et al. 2016, Narayanan et al. 2016). Altogether, there is an unmet need for the development of novel therapeutic strategies including tissueselective AR modulators (SARMs; (Estébanez-Perpiñá et al. 2007b, Dalton 2017, Narayanan et al. 2018)) that may overcome the problems encountered by currently used drugs. 
Most therapeutic strategies to date have focused on the development of small-molecule compounds that compete with receptor binding to natural hormones (so called "LBP-focused strategies"). However, the recent advances in the structure and function of NRs discussed above have largely expanded the space for pharmacological intervention. First, we mention that AR chaperones had been proposed as potential therapeutic targets against PCa and, after initial failures, heat shock proteins, and in particular Hsp90, are currently considered viable targets to treat PCa (Eskew et al. 2011, Centenera et al. 2012, Centenera et al. 2013a, He et al. 2013). Indeed, inhibitors of Hsp90 C-terminal domain have been recently shown to inhibit growth of various PCa cell lines without inducing expression of other chaperones (Armstrong et al. 2016).

Novel strategies that directly target the NR include blocking receptor interactions with specific coactivators (Azad et al. 2015, Guy et al. 2015, Foley and Mitsiades 2016), directly targeting NR binding to cognate DNA sequences or interfering with DBD dimerization (Dalal et al. 2017), but also modulating ligandindependent functions (reviewed in (Caboni and Lloyd 2013)). Also along these lines, the AR-NTD has been explored as drug target for AR function control, in particular for management of its ligand-independent truncated variants (De Mol et al. 2016, Imamura and Sadar 2016, Kumar et al. 2016, Monaghan and McEwan 2016).

It is believed that conformational changes elicited upon ligand binding are ultimately responsible for the different activity profiles exhibited by therapeutic compounds in different cell types, similar to what has been shown for other NRs

578 (Srinivasan et al. 2013, Nwachukwu et al. 2016). Given that these signals might propagate through the whole multi-domain protein, controlling NR functions by 
580 targeting novel unexplored sites is an attractive but challenging alternative. Most importantly, apart from the classical modulators targeting the LBP site, synthetic allosteric modulators are currently under investigation, thus substantially broadening the chemical space for novel antiandrogens (Buzón et al. 2012). In this manner, the AR LBP shall no longer be seen as the only pocket suitable for pharmacological intervention, but all NR domains and their protein-protein interaction sites are envisioned as potential drug targets (Estébanez-Perpiñá et al. 2007b, Buzón et al. 2012, Nadal et al. 2017, Badders et al. 2018). In this regard, we recall that both AF-2 and BF-3 sites are druggable, and are ideal candidates for off-LBP strategies (Estébanez-Perpiñá et al. 2007b, Buzón et al. 2012, Ravindranathan et al. 2013, Badders et al. 2018). Most notably, AF2targeting compounds have been recently validated as potent androgen-sparing strategies for SBMA therapy (Badders et al. 2018). Last but not least, interfering with the non-canonical dimerization interfaces of the AR and other oxosteroid receptors (Nadal et al. 2017, Fuentes-Prior et al. 2019) offers hitherto unforeseen possibilities for the regulation of NR activities, and thus for the development of novel pharmaceutical drugs. 


\section{Declaration of interest}

600 The authors declare that there is no conflict of interests.

601

602 Funding

603 EEP expresses her deepest gratitude to the generous and continuous private 604 donations from GEC. EEP, PFP and PP acknowledge the RED Nacional de 605 Receptores Nucleares (NurCaMeln: SAF2017-71878-REDT and SAF2015606 71878-REDT). EEP acknowledges the BFU-Retos2017-86906-R, PFP the 607 SAF2014-57994-R, PP the SAF2017-88046-R and AR the RTI2018-096735-B608100 grants from the MINECO. EEP and PFP are thankful for the 609 Caixalmpulse2017 (ARDIs) from La Caixa (Fundación Bancaria Caja de Ahorros 610 y Pensiones de Barcelona, Obra Social La Caixa y Caixa Risc), and SGR2017 611 and LLAVOR2018 grants from the Generalitat de Catalunya. EEP acknowledges 612 the F2I-FVAL and F2I-MiR grants from the EU FEDER and the Fundacio Bosch 613 i Gimpera (FBG). 


\section{Figure 1 legend}

617 Schematic representation of the domain organization in steroid receptors. Note 618 the common modular protein structure of four main elements: the $\mathrm{N}$-terminal 619 domain (NTD), which contains the activating function 1 (AF1), the DNA-binding 620 domain (DBD), a hinge region $(H)$, and the actual ligand binding domain (LBD), 621 which contains the activating function 2 (AF2) assembled by residues from 622 helices $\mathrm{H} 3, \mathrm{H} 4, \mathrm{H} 5$ and $\mathrm{H} 12$. The so called "F domain", located at the C-terminal end of the receptor, folds back and covers part of the globular LBD in all 624 oxosteroid receptors, but not in $E R \alpha / \beta$, whose $F$ domains differ strongly from the one well-conserved in oxosteroid receptors. Other NRs such as the thyroid receptor (TR) lack an F domain altogether. Note also that the NTDs are highly 627 variable in sequence and length. The AR-NTD can be further dissected into two partly overlapping transcription-activation units, TAU1 comprising residues 142485 and TAU5 including residues 360-528 (Jenster et al. 1995, Hilser et al. 2012).

630 Similarly, studies of translational isoforms with variable lengths of the GR-NTD have also found two coupled but thermodynamically distinct regions (Brinkmann et al. 1989, Michigami et al. 1999, Li et al. 2012). At least in the case of these two oxosteroid receptors, the main determinants for transactivation map to their highly similar AF-1 sites (46\% sequence identity; (Kumar et al. 2004, McEwan et al. 2007, De Mol et al. 2018)). 


\section{$637 \quad$ Figure 2 legend}

638 Functional surfaces of the androgen receptor. (A) Surface view of the AR-LBD 639 dimer structure (derived from PDB 5JJM) highlighting the BF3 pocket (pink 640 surface) with a small molecule ([4-(4-hydroxy-3-iodo-phenoxy)-3,5-diiodo641 phenyl]-acetic acid) bound, an UBA3-derived peptide bound to the AF2 pocket, 642 and the hormone (dihydrotestosterone, DHT) occupying to the ligand-binding 643 pocket (LBP). Note that the AR-LBD core dimer is closely packed; it buries a quite 644 extensive interface of $\approx 1,000 \AA^{2}$ of solvent exposed surface from each AR-LBD 645 partner. (B) View of the AR-LBD crystal structure highlighting the four 646 independent AR-LBD molecules found in the asymmetric unit. Notice that the two 647 middle AR-LBD monomers (colored grey) form a symmetrical core dimer, while 648 the two peripheral molecules (colored light pink) are associated through the BF649 3 grooves (highlighted in pink). 


\section{$651 \quad$ Figure 3 legend}

652 Crystal structures of homodimeric ligand-binding domains from various nuclear receptors. (A) Overall structure of the AR-LBD core dimer (PDB 5JJM). The two monomers are depicted as cartoons showing helices in blue and loops in pink; helices $\mathrm{H} 5, \mathrm{H} 9, \mathrm{H} 10-11$ and $\mathrm{H} 12$ are marked. Note that the AR-LBD mainly dimerizes through helices $\mathrm{H} 5$ of both monomers. The bound hormone 657 (dihydrotestosterone, DHT) and the UBA3 peptide are shown as pink spheres and as a magenta cartoon, respectively. (B) Overall structure of the first reported GR-LBD dimer (PDB 1M2Z). The two monomers are depicted as cartoons showing helices in blue and loops in pink; helices $\mathrm{H} 5, \mathrm{H} 9$, and $\mathrm{H} 10-11$ are highlighted. The bound hormone (dexamethasone, DEX) and the coactivator (TIF2) peptide are shown as pink spheres and as a blue cartoon, respectively. Note the topological equivalence to the AR-LBD dimer depicted in panel $A$, in spite of less intimate contacts at the intermonomer interface. (C) Overall structure of the ER-LBD dimer (PDB 1ERE). The two monomers are depicted as cartoons showing helices in pink and loops in red; helices $\mathrm{H} 9$ and $\mathrm{H} 10-11$ are indicated. Note that the ER-LBD dimerizes according to the 'canonical' mechanism, i.e. through helices $\mathrm{H} 10-11$ of each monomer. The hormone (17beta-estradiol, EST) is shown as blue spheres. (D) Overall structure of the TR-LBD dimer (PDB 2PIN). The two monomers are shown as cartoons with helices in green and loops in 671 pink; helices H9, H10-11 and H12 are labeled. The ligand ([4-(4-hydroxy-3-iodo672 phenoxy)-3,5-diiodo-phenyl]-acetic acid, 4HY) is shown as pink spheres. Dashed lines indicate parts of the structure that were not visible in the electron density maps. 


\section{$676 \quad$ Figure 4 legend}

677 Proximity of functionally relevant areas in non-canonical dimers. (A) Close-up of 678 the AR-LBD dimerization interface. Monomers are colored light pink and blue, 679 respectively, and the DHT molecules are shown as color-coded Van-der-Waals 680 spheres. Residues are shown as color-coded sticks (oxygen, red; nitrogen, blue; 681 carbon, yellow or brown) and labeled. Note that most residues making important 682 contributions to this interface possess hydrophobic/aromatic side chains (e.g., 683 V685, W752, F755, V758, Y764, and P802). The location of residue R753 is also noteworthy, as its side chain contacts the DHT molecule bound inside the internal ligand-binding pocket (LBP) from its "own" monomer, while its main chain atoms form part of the dimer interface, and in particular interact with N757 from the second monomer. In this manner, hormone binding and receptor dimerization appear to be intimately coupled in the AR. (B) Close-up of the AR-LBD surface (as seen in PDB 1XOW), highlighting the proximity of the AF-2 pocket (colored blue; the bound $\mathrm{NH}_{2}$-terminal peptide of the receptor is colored cyan) to the LBP 691 (with bound methyltrienolone/R1881 colored magenta). 


\section{$693 \quad$ Figure 5 legend}

694 Mutations that affect the non-canonical, AR-like dimerization interface are linked 695 to various conditions. The LBD dimers of all four analyzed receptors are 696 represented as grey cartoons. (A, B) AR-LBD (PDB 5JJM) with the side chains 697 of all mutated interface residues shown with all their non-hydrogen atoms as 698 sticks and surface, colored red for mutations reported in PCa patients (A), or blue 699 for those linked to AIS (B). Mutations have been retrieved from the Androgen 700 Receptor Gene Mutations Database (http://androgendb.mcgill.ca/). (C) GR-LBD 701 (PDB 1M2Z) with the side chains of all mutated interface residues shown with all 702 their non-hydrogen atoms as sticks and surface, colored pink to highlight those 703 residues linked to glucocorticoid hormone resistance. Some of these residues 704 have been associated with primary generalized Chrousos syndrome. (D) Cartoon representation of the TR-LBD dimer (grey, PDB 2PIN) with the side chains of all mutated interface residues shown with all their non-hydrogen atoms as sticks and surface, colored green to highlight those residues associated with thyroid 708 hormone resistance. 
713 Table 1 legend

714 Mutations within the non-canonical dimerization interface are linked to various

715 human conditions. Residues from the non-canonical dimerization interface of the

716 AR-LBD were aligned to those of the corresponding domains in GR, ER and TR.

717 Missense mutations that affect these topologically equivalent residues are given,

718 along with the associated disease. Note in particular that several mutations affect

719 topologically equivalent residues in AR-LBD and TR-LBD. Note also that

720 replacement of the highly conserved residue $\mathrm{R} 753$ of AR-LBD, which

721 corresponds to R611 of GR-LBD, R394 of ER-LBD and R320 of TR-LBD, causes

722 hormone resistance in all receptors. 
724

\section{References}

Adams, M., Matthews, C., Collingwood, T. N., Tone, Y., Beck-Peccoz, P. \& Chatterjee, K. K. (1994) Genetic analysis of 29 kindreds with generalized and pituitary resistance to thyroid hormone. Journal of Clinical Investigation 94 506-515.

Aggarwal, R. R., Feng, F. Y. \& Small, E. J. (2017) Emerging categories of disease in advanced prostate cancer and their therapeutic implications. Oncology-New York 31 467-474.

Agoulnik, I. U., Tong, X. W., Fischer, D. C., Körner, K., Atkinson, N. E., Edwards, D. P., Headon, D. R., Weigel, N. L. \& Kieback, D. G. (2004) A germline variation in the progesterone receptor gene increases transcriptional activity and may modify ovarian cancer risk. Journal of Clinical Endocrinology and Metabolism 89 6340-6347.

Armenia, J., Wankowicz, S. A. M., Liu, D., Gao, J., Kundra, R., Reznik, E., Chatila, W. K., Chakravarty, D., Han, G. C., Coleman, I., et al. (2018) The long tail of oncogenic drivers in prostate cancer. Nature Genetics 50 645-651.

Armstrong, H. K., Koay, Y. C., Irani, S., Das, R., Nassar, Z. D., Selth, L. A., Centenera, M. M., McAlpine, S. R., Butler, L. M. \& Butler, L. M. (2016) A novel class of Hsp90 C-terminal modulators have pre-clinical efficacy in prostate tumor cells without induction of a heat shock response. The Prostate 76 1546-1559.

Arora, K. \& Barbieri, C. E. (2018) Molecular subtypes of prostate cancer. Current Oncology Reports 20 58-58.

Arora, Vivek K., Schenkein, E., Murali, R., Subudhi, Sumit K., Wongvipat, J., Balbas, Minna D., Shah, N., Cai, L., Efstathiou, E., Logothetis, C., et al. (2013) Glucocorticoid receptor confers resistance to antiandrogens by bypassing androgen receptor blockade. Cell 155 1309-1322.

Augello, M. A., Liu, D., Deonarine, L. D., Robinson, B. D., Huang, D., Stelloo, S., Blattner, M., Doane, A. S., Wong, E. W. P., Chen, Y., et al. (2019) CHD1 loss alters AR binding at lineagespecific enhancers and modulates distinct transcriptional programs to drive prostate tumorigenesis. Cancer Cell 35 603-617.e8.

Azad, A. A., Zoubeidi, A., Gleave, M. E. \& Chi, K. N. (2015) Targeting heat shock proteins in metastatic castration-resistant prostate cancer. Nature Reviews Urology 12 26-36.

Badders, N. M., Korff, A., Miranda, H. C., Vuppala, P. K., Smith, R. B., Winborn, B. J., Quemin, E. R., Sopher, B. L., Dearman, J., Messing, J., et al. (2018) Selective modulation of the androgen receptor AF2 domain rescues degeneration in spinal bulbar muscular atrophy. Nature Medicine 24 427-437.

Bai, S., He, B. \& Wilson, E. M. (2005) Melanoma antigen gene protein MAGE-11 regulates androgen receptor function by modulating the interdomain interaction. Molecular and Cellular Biology 25 1238-1257.

Balbas, M. D., Evans, M. J., Hosfield, D. J., Wongvipat, J., Arora, V. K., Watson, P. A., Chen, Y., Greene, G. L., Shen, Y. \& Sawyers, C. L. (2013) Overcoming mutation-based resistance to antiandrogens with rational drug design. eLife 2 e00499-e00499.

Baumgart, S. J. \& Haendler, B. (2017) Exploiting epigenetic alterations in prostate cancer. International Journal of Molecular Sciences 18 1017-1017.

Berglund, A. E., Rounbehler, R. J., Gerke, T., Awasthi, S., Cheng, C.-H., Takhar, M., Davicioni, E., Alshalalfa, M., Erho, N., Klein, E. A., et al. (2018) Distinct transcriptional repertoire of the androgen receptor in ETS fusion-negative prostate cancer. Prostate Cancer and Prostatic Diseases.

Bianchetti, L., Wassmer, B., Defosset, A., Smertina, A., Tiberti, M. L., Stote, R. H. \& Dejaegere, A. (2018) Alternative dimerization interfaces in the glucocorticoid receptor- $\alpha$ ligand binding domain. Biochimica et Biophysica Acta (BBA) - General Subjects 1862 1810-1825.

Bledsoe, R. K., Montana, V. G., Stanley, T. B., Delves, C. J., Apolito, C. J., McKee, D. D., Consler, T. G., Parks, D. J., Stewart, E. L., Willson, T. M., et al. (2002) Crystal structure of the 
glucocorticoid receptor ligand binding domain reveals a novel mode of receptor dimerization and coactivator recognition. Cell 110 93-105.

Bohl, C. E., Wu, Z., Miller, D. D., Bell, C. E. \& Dalton, J. T. (2007) Crystal structure of the T877A human androgen receptor ligand-binding domain complexed to cyproterone acetate provides insight for ligand-induced conformational changes and structure-based drug design. Journal of Biological Chemistry 282 13648-13655.

Bourguet, W., Vivat, V., Wurtz, J. M., Chambon, P., Gronemeyer, H. \& Moras, D. (2000) Crystal structure of a heterodimeric complex of RAR and RXR ligand-binding domains. Molecular cell 5 289-98.

Brinkmann, A. O., Faber, P. W., van Rooij, H. C. J., Kuiper, G. G. J. M., Ris, C., Klaassen, P., van der Korput, J. A. G. M., Voorhorst, M. M., van Laar, J. H., Mulder, E., et al. (1989) The human androgen receptor: Domain structure, genomic organization and regulation of expression. Journal of Steroid Biochemistry 34 307-310.

Brzozowski, A. M., Pike, A. C. W., Dauter, Z., Hubbard, R. E., Bonn, T., Engström, O., Öhman, L., Greene, G. L., Gustafsson, J.-Å. \& Carlquist, M. (1997) Molecular basis of agonism and antagonism in the oestrogen receptor. Nature 389 753-758.

Buzón, V., Carbó, L. R., Estruch, S. B., Fletterick, R. J. \& Estébanez-Perpiñá, E. (2012) A conserved surface on the ligand binding domain of nuclear receptors for allosteric control. Molecular and Cellular Endocrinology 348 394-402.

Caboni, L. \& Lloyd, D. G. (2013) Beyond the ligand-binding pocket: Targeting alternate sites in nuclear receptors. Medicinal Research Reviews 29 1292-1327.

Carroll, J. S. (2016) Mechanisms of oestrogen receptor (ER) gene regulation in breast cancer. European Journal of Endocrinology 175 R41-R49.

Carver, B. S., Tran, J., Gopalan, A., Chen, Z., Shaikh, S., Carracedo, A., Alimonti, A., Nardella, C., Varmeh, S., Scardino, P. T., et al. (2009) Aberrant ERG expression cooperates with loss of PTEN to promote cancer progression in the prostate. Nature Genetics $\mathbf{4 1} 619$.

Casey, O. M., Fang, L., Hynes, P. G., Abou-Kheir, W. G., Martin, P. L., Tillman, H. S., Petrovics, G., Awwad, H. O., Ward, Y., Lake, R., et al. (2012) TMPRSS2-driven ERG expression in vivo increases self-renewal and maintains expression in a castration resistant subpopulation. PLOS ONE 7 e41668.

Centenera, M. M., Fitzpatrick, A. K., Tilley, W. D. \& Butler, L. M. (2013a) Hsp90: Still a viable target in prostate cancer. Biochimica et Biophysica Acta (BBA) - Reviews on Cancer 1835 211-218.

Centenera, M. M., Gillis, J. L., Hanson, A. R., Jindal, S., Taylor, R. A., Risbridger, G. P., Sutherland, P. D., Scher, H. I., Raj, G. V., Knudsen, K. E., et al. (2012) Evidence for efficacy of new Hsp90 inhibitors revealed by ex vivo culture of human prostate tumors. Clinical Cancer Research 18 3562-3570.

Centenera, M. M., Harris, J. M., Tilley, W. D. \& Butler, L. M. (2008) The contribution of different androgen receptor domains to receptor dimerization and signaling. Molecular Endocrinology 22 2373-2382.

Centenera, M. M., Raj, G. V., Knudsen, K. E., Tilley, W. D. \& Butler, L. M. (2013b) Ex vivo culture of human prostate tissue and drug development. Nature Reviews Urology 10 483-487.

Centenera, M. M., Selth, L. A., Ebrahimie, E., Butler, L. M. \& Tilley, W. D. (2018) New opportunities for targeting the androgen receptor in prostate cancer. Cold Spring Harbor Perspectives in Medicine 8 a030478-a030478.

Cioni, B., Zwart, W. \& Bergman, A. M. (2018) Androgen receptor moonlighting in the prostate cancer microenvironment. Endocrine-Related Cancer 25 R331-R349.

Clocchiatti, A., Ghosh, S., Procopio, M.-G., Mazzeo, L., Bordignon, P., Ostano, P., Goruppi, S., Bottoni, G., Katarkar, A., Levesque, M., et al. (2018) Androgen receptor functions as transcriptional repressor of cancer-associated fibroblast activation. Journal of Clinical Investigation 128 5531-5548. 
Cortes, C. J. \& La Spada, A. R. (2018) X-linked spinal and bulbar muscular atrophy: From clinical genetic features and molecular pathology to mechanisms underlying disease toxicity. Advances in Experimental Medicine and Biology 1049 103-133.

Cotter, K. A. \& Rubin, M. A. (2018) Sequence of events in prostate cancer. Nature 560 557-559.

Chandra, V., Huang, P., Hamuro, Y., Raghuram, S., Wang, Y., Burris, T. P. \& Rastinejad, F. (2008) Structure of the intact PPAR- $\gamma$-RXR- $\alpha$ nuclear receptor complex on DNA. Nature $456350-$ 356.

Chandra, V., Huang, P., Potluri, N., Wu, D., Kim, Y. \& Rastinejad, F. (2013) Multidomain integration in the structure of the HNF-4 $\alpha$ nuclear receptor complex. Nature $495394-$ 398.

Chandra, V., Wu, D., Li, S., Potluri, N., Kim, Y. \& Rastinejad, F. (2017) The quaternary architecture of RAR $\beta$-RXR $\alpha$ heterodimer facilitates domain-domain signal transmission. Nature Communications 8 868-868.

Charmandari, E., Ichijo, T., Jubiz, W., Baid, S., Zachman, K., Chrousos, G. P. \& Kino, T. (2008) A novel point mutation in the amino terminal domain of the human glucocorticoid receptor (hGR) gene enhancing hGR-mediated gene expression. The Journal of Clinical Endocrinology \& Metabolism 93 4963-4968.

Charmandari, E., Kino, T. \& Chrousos, G. P. (2013) Primary generalized familial and sporadic glucocorticoid resistance (Chrousos syndrome) and hypersensitivity. IN MAGHNIE, M., LOCHE, S., CAPPA, M., GHIZZONI, L. \& LORINI, R. (Eds.) Hormone Resistance and Hypersensitivity. From Genetics to Clinical Management.

Chatonnet, F., Guyot, R., Benoit, G. \& Flamant, F. (2013) Genome-wide analysis of thyroid hormone receptors shared and specific functions in neural cells. Proceedings of the National Academy of Sciences of the United States of America 110 E766-E775.

Chen, Y., Chi, P., Rockowitz, S., laquinta, P. J., Shamu, T., Shukla, S., Gao, D., Sirota, I., Carver, B. S., Wongvipat, J., et al. (2013) ETS factors reprogram the androgen receptor cistrome and prime prostate tumorigenesis in response to PTEN loss. Nature Medicine 191023.

Chen, Y., Sawyers, C. L. \& Scher, H. I. (2008) Targeting the androgen receptor pathway in prostate cancer. Current Opinion in Pharmacology 8 440-448.

Dalal, K., Che, M., Que, N. S., Sharma, A., Yang, R., Lallous, N., Borgmann, H., Ozistanbullu, D., Tse, R., Ban, F., et al. (2017) Bypassing drug-resistance mechanisms of prostate cancer with small-molecules that target androgen receptor chromatin interactions. Molecular Cancer Therapeutics 16 2281-2291.

Dalal, K., Roshan-Moniri, M., Sharma, A., Li, H., Ban, F., Hessein, M., Hsing, M., Singh, K., LeBlanc, E., Dehm, S., et al. (2014) Selectively targeting the DNA-binding domain of the androgen receptor as a prospective therapy for prostate cancer. Journal of Biological Chemistry 289 26417-26429.

Dalton, J. T. (2017) The long and winding road for selective androgen receptor modulators. British Journal of Clinical Pharmacology 83 2131-2133.

Dasgupta, S., Lonard, D. M. \& O'Malley, B. W. (2014) Nuclear receptor coactivators: Master regulators of human health and disease. Annual Review of Medicine 65 279-292.

De Mol, E., Fenwick, R. B., Phang, C. T. W., Buzón, V., Szulc, E., De La Fuente, A., Escobedo, A., García, J., Bertoncini, C. W., Estébanez-Perpiñá, E., et al. (2016) EPI-001, a compound active against castration-resistant prostate cancer, targets transactivation unit 5 of the androgen receptor. ACS Chemical Biology 11 2499-2505.

De Mol, E., Szulc, E., Di Sanza, C., Martínez-Cristóbal, P., Bertoncini, C. W., Fenwick, R. B., FrigoléVivas, M., Masín, M., Hunter, I., Buzón, V., et al. (2018) Regulation of androgen receptor activity by transient interactions of its transactivation domain with general transcription regulators. Structure 26 145-152.e3.

Dehm, S. M. \& Tindall, D. J. (2011) Alternatively spliced androgen receptor variants. Endocrine Related Cancer 18 R183-R196. 
del Sol, A., Fujihashi, H., Amoros, D. \& Nussinov, R. (2006) Residues crucial for maintaining short paths in network communication mediate signaling in proteins. Molecular Systems Biology 2 2006.0019-2006.0019.

Ellis, J. A., Stebbing, M. \& Harrap, S. B. (2001) Polymorphism of the androgen receptor gene is associated with male pattern baldness. Journal of Investigative Dermatology 116 452455.

Eskew, J. D., Sadikot, T., Morales, P., Duren, A., Dunwiddie, I., Swink, M., Zhang, X., Hembruff, S., Donnelly, A., Rajewski, R. A., et al. (2011) Development and characterization of a novel $\mathrm{C}$-terminal inhibitor of $\mathrm{Hsp90}$ in androgen dependent and independent prostate cancer cells. BMC Cancer 11 1-16.

Estebanez-Perpina, E., Arnold, L. A., Nguyen, P., Rodrigues, E. D., Mar, E., Bateman, R., Pallai, P., Shokat, K. M., Baxter, J. D., Guy, R. K., et al. (2007) A surface on the androgen receptor that allosterically regulates coactivator binding. Proceedings of the National Academy of Sciences 104 16074-16079.

Estébanez-Perpiñá, E., Arnold, L. A., Jouravel, N., Togashi, M., Blethrow, J., Mar, E., Nguyen, P., Phillips, K. J., Baxter, J. D., Webb, P., et al. (2007a) Structural insight into the mode of action of a direct inhibitor of coregulator binding to the thyroid hormone receptor. Molecular Endocrinology 21 2919-2928.

Estébanez-Perpiñá, E., Jouravel, N. \& Fletterick, R. J. (2007b) Perspectives on designs of antiandrogens for prostate cancer. Expert Opinion on Drug Discovery 2 1341-1355.

Estébanez-Perpiñá, E., Moore, J. M. R., Mar, E., Delgado-Rodrigues, E., Nguyen, P., Baxter, J. D., Buehrer, B. M., Webb, P., Fletterick, R. J. \& Guy, R. K. (2005) The molecular mechanisms of coactivator utilization in ligand-dependent transactivation by the androgen receptor. The Journal of Biological Chemistry 280 8060-8068.

Evans, R. M. \& Mangelsdorf, D. J. (2014) Nuclear receptors, RXR, and the big bang. Cell 157255 266.

Faus, H. \& Haendler, B. (2006) Post-translational modifications of steroid receptors. Biomedicine and Pharmacotherapy 60 520-528.

Fernandez, E. J. (2018) Allosteric pathways in nuclear receptors - Potential targets for drug design. Pharmacology \& Therapeutics 183 152-159.

Fernandez, E. J., Gahlot, V., Rodriguez, C. \& Amburn, J. (2017) DNA-induced unfolding of the thyroid hormone receptor $\alpha$ A/B domain through allostery. FEBS Open Bio 7 854-864.

Foley, C. \& Mitsiades, N. (2016) Moving beyond the androgen receptor (AR): Targeting ARinteracting proteins to treat prostate cancer. Hormones and Cancer 7 84-103.

Frank, F., Okafor, C. D. \& Ortlund, E. A. (2018) The first crystal structure of a DNA-free nuclear receptor DNA binding domain sheds light on DNA-driven allostery in the glucocorticoid receptor. Scientific Reports 813497.

Fuentes-Prior, P., Rojas, A., Hagler, A. T. \& Estébanez-Perpiñá, E. (2019) Diversity of quaternary structures regulates nuclear receptor activities. Trends in Biochemical Sciences 44 2-6.

Gallastegui, N., Mackinnon, J. A. G., Fletterick, R. J. \& Estébanez-Perpiñá, E. (2015) Advances in our structural understanding of orphan nuclear receptors. Trends in Biochemical Sciences 40 25-35.

Giacinti, S., Poti, G., Roberto, M., Macrini, S., Bassanelli, M., Di Pietro, F., Aschelter, A. M., Ceribelli, A., Ruggeri, E. M. \& Marchetti, P. (2018) Molecular basis of drug resistance and insights for new treatment approaches in MCRPC. Anticancer Research 38 6029-6039.

Gibson, D. A., Saunders, P. T. K. \& McEwan, I. J. (2018) Androgens and androgen receptor: Above and beyond. Molecular and Cellular Endocrinology 465 1-3.

Gioeli, D. \& Paschal, B. M. (2012) Post-translational modification of the androgen receptor. Molecular and Cellular Endocrinology 352 70-78.

Giudici, M., Goni, S., Fan, R. \& Treuter, E. (2016) Nuclear receptor coregulators in metabolism and disease. Handbook of experimental pharmacology. 
Gottlieb, B., Beitel, L. K., Wu, J., Elhaji, Y. A. \& Trifiro, M. (2004) Nuclear receptors and disease: androgen receptor. Essays in biochemistry 40 121-36.

Grasso, C. S., Wu, Y.-M., Robinson, D. R., Cao, X., Dhanasekaran, S. M., Khan, A. P., Quist, M. J., Jing, X., Lonigro, R. J., Brenner, J. C., et al. (2012) The mutational landscape of lethal castration-resistant prostate cancer. Nature 487 239-243.

Grosdidier, S., Carbó, L. R., Buzón, V., Brooke, G., Nguyen, P., Baxter, J. D., Bevan, C., Webb, P., Estébanez-Perpiñá, E. \& Fernández-Recio, J. (2012) Allosteric conversation in the androgen receptor ligand-binding domain surfaces. Molecular Endocrinology 26 10781090.

Guy, N. C., Garcia, Y. A. \& Cox, M. B. (2015) Therapeutic targeting of the FKBP52 co-chaperone in steroid hormone receptor-regulated physiology and disease. Current Molecular Pharmacology 9 109-125.

Hay, C. W. \& McEwan, I. J. (2012) The impact of point mutations in the human androgen receptor: Classification of mutations on the basis of transcriptional activity. PLOS ONE 7 e32514.

He, B., Gampe, R. T., Kole, A. J., Hnat, A. T., Stanley, T. B., An, G., Stewart, E. L., Kalman, R. I., Minges, J. T. \& Wilson, E. M. (2004) Structural basis for androgen receptor interdomain and coactivator interactions suggests a transition in nuclear receptor activation function dominance. Molecular Cell 16 425-438.

He, B. \& Wilson, E. M. (2002) The $\mathrm{NH}_{2}$-terminal and carboxyl-terminal interaction in the human androgen receptor. Molecular Genetics and Metabolism 75 293-298.

He, S., Zhang, C., Shafi, A. A., Sequeira, M., Acquaviva, J., Friedland, J. C., Sang, J., Smith, D. L., Weigel, N. L., Wada, Y., et al. (2013) Potent activity of the Hsp90 inhibitor ganetespib in prostate cancer cells irrespective of androgen receptor status or variant receptor expression. International Journal of Oncology 42 35-43.

Hermanson, O., Glass, C. K. \& Rosenfeld, M. G. (2002) Nuclear receptor coregulators: multiple modes of modification. Trends in Endocrinology \& Metabolism 13 55-60.

Hernández, M. P., Chadli, A. \& Toft, D. O. (2002) HSP40 binding is the first step in the HSP9O chaperoning pathway for the progesterone receptor. Journal of Biological Chemistry 277 11873-11881.

Hilser, V. J., Wrabl, J. O. \& Motlagh, H. N. (2012) Structural and energetic basis of allostery. Annual Review of Biophysics 41 585-609.

Ho, Y. \& Dehm, S. M. (2017) Androgen receptor rearrangement and splicing variants in resistance to endocrine therapies in prostate cancer. Endocrinology 158 1533-1542.

Holzer, G., Roux, N. \& Laudet, V. (2017) Evolution of ligands, receptors and metabolizing enzymes of thyroid signaling. Molecular and Cellular Endocrinology 459 5-13.

Huang, P., Chandra, V. \& Rastinejad, F. (2010) Structural overview of the nuclear receptor superfamily: Insights into physiology and therapeutics. Annual Review of Physiology 72 247-272.

Huang, S., Gulzar, Z. G., Salari, K., Lapointe, J., Brooks, J. D. \& Pollack, J. R. (2012) Recurrent deletion of CHD1 in prostate cancer with relevance to cell invasiveness. Oncogene $\mathbf{3 1}$ 4164-4170.

Huang, W., Peng, Y., Kiselar, J., Zhao, X., Albaqami, A., Mendez, D., Chen, Y., Chakravarthy, S., Gupta, S., Ralston, C., et al. (2018) Multidomain architecture of estrogen receptor reveals interfacial cross-talk between its DNA-binding and ligand-binding domains. Nature Communications 9 3520-3520.

Huber, B. R., Desclozeaux, M., West, B. L., Cunha-Lima, S. T., Nguyen, H. T., Baxter, J. D., Ingraham, H. A. \& Fletterick, R. J. (2003a) Thyroid hormone receptor- $\beta$ mutations conferring hormone resistance and reduced corepressor release exhibit decreased stability in the N-terminal ligand-binding domain. Molecular Endocrinology 17 107-116. 
Huber, B. R., Sandler, B., West, B. L., Cunha Lima, S. T., Nguyen, H. T., Apriletti, J. W., Baxter, J. D. \& Fletterick, R. J. (2003b) Two resistance to thyroid hormone mutants with impaired hormone binding. Molecular Endocrinology 17 643-652.

Hughes, I. A., Werner, R., Bunch, T. \& Hiort, O. (2012) Androgen insensitivity syndrome. Semin Reprod Med 30 432-442.

Hur, E., Pfaff, S. J., Payne, E. S., Grøn, H., Buehrer, B. M. \& Fletterick, R. J. (2004) Recognition and accommodation at the androgen receptor coactivator binding interface. PLoS Biology 2 E274-E274.

Hurt, D. E., Mayama, T., Suzuki, S., Kino, T. \& Charmandari, E. (2016) Structural analysis on the pathologic mutant glucocorticoid receptor ligand-binding domains. Molecular Endocrinology 30 173-188.

Imamura, Y. \& Sadar, M. D. (2016) Androgen receptor targeted therapies in castration-resistant prostate cancer: Bench to clinic. International Journal of Urology 23 654-665.

Jenster, G., van der Korput, H. A., Trapman, J. \& Brinkmann, A. O. (1995) Identification of two transcription activation units in the $\mathrm{N}$-terminal domain of the human androgen receptor. The Journal of Biological Chemistry.

Jernberg, E., Bergh, A. \& Wikström, P. (2017) Clinical relevance of androgen receptor alterations in prostate cancer. Endocrine Connections 6 R146-R161.

Jin, H.-J., Kim, J. \& Yu, J. (2013) Androgen receptor genomic regulation. Translational Andrology and Urology 2 157-177.

Joseph, J. D., Lu, N., Qian, J., Sensintaffar, J., Shao, G., Brigham, D., Moon, M., Maneval, E. C., Chen, I., Darimont, B., et al. (2013) A clinically relevant androgen receptor mutation confers resistance to second-generation antiandrogens enzalutamide and ARN-509. Cancer Discovery 3 1020-1029.

Jouravel, N., Sablin, E., Togashi, M., Baxter, J. D., Webb, P. \& Fletterick, R. J. (2009) Molecular basis for dimer formation of TR $\beta$ variant D355R. Proteins: Structure, Function, and Bioinformatics 75 111-117.

Karamouzis, M. V., Papavassiliou, K. A., Adamopoulos, C. \& Papavassiliou, A. G. (2016) Targeting androgen/estrogen receptors crosstalk in cancer. Trends in Cancer 2 35-48.

Karthaus, W. R. \& Sawyers, C. L. (2018) Strategies to identify and target cells of origin in prostate cancer. JNCI: Journal of the National Cancer Institute.

Katzenellenbogen, J. A., Mayne, C. G., Katzenellenbogen, B. S., Greene, G. L. \& Chandarlapaty, S. (2018) Structural underpinnings of oestrogen receptor mutations in endocrine therapy resistance. Nature Reviews Cancer 18 377-388.

Kauppi, B., Jakob, C., Färnegårdh, M., Yang, J., Ahola, H., Alarcon, M., Calles, K., Engström, O., Harlan, J., Muchmore, S., et al. (2003) The three-dimensional structures of antagonistic and agonistic forms of the glucocorticoid receptor ligand-binding domain: RU-486 INDUCES A TRANSCONFORMATION THAT LEADS TO ACTIVE ANTAGONISM. Journal of Biological Chemistry 278 22748-22754.

Khorasanizadeh, S. \& Rastinejad, F. (2016) Visualizing the architectures and interactions of nuclear receptors. Endocrinology 157 4212-4221.

King, J. C., Xu, J., Wongvipat, J., Hieronymus, H., Carver, B. S., Leung, D. H., Taylor, B. S., Sander, C., Cardiff, R. D., Couto, S. S., et al. (2009) Cooperativity of TMPRSS2-ERG with PI3-kinase pathway activation in prostate oncogenesis. Nature Genetics 41 524-526.

Kino, T. \& Chrousos, G. P. (2001) Glucocorticoid and mineralocorticoid resistance/hypersensitivity syndromes. Journal of Endocrinology 169 437-445.

Kino, T., Vottero, A., Charmandari, E. \& Chrousos, G. P. (2002) Familial/sporadic glucocorticoid resistance syndrome and hypertension. Annals of the New York Academy of Sciences 970 101-111.

Kita, K., Shiota, M., Tanaka, M., Otsuka, A., Matsumoto, M., Kato, M., Tamada, S., Iwao, H., Miura, K., Nakatani, T., et al. (2017) Heat shock protein 70 inhibitors suppress androgen receptor expression in LNCaP95 prostate cancer cells. Cancer Science 108 1820-1827. 
Knudsen, K. E. \& Penning, T. M. (2010) Partners in crime: Deregulation of AR activity and androgen synthesis in prostate cancer. Trends in Endocrinology and Metabolism 21 315324.

Kojetin, D. J., Burris, T. P., Jensen, E. V. \& Khan, S. A. (2008) Implications of the binding of tamoxifen to the coactivator recognition site of the estrogen receptor. EndocrineRelated Cancer 15 851-870.

Kokontis, J. M. \& Liao, S. (1998) Molecular action of androgen in the normal and neoplastic prostate. Vitamins and Hormones 55 219-307.

Koryakina, Y., Ta, H. Q. \& Gioeli, D. (2014) Androgen receptor phosphorylation: Biological context and functional consequences. Endocrine-Related Cancer 21.

Kumar, A., Coleman, I., Morrissey, C., Zhang, X., True, L. D., Gulati, R., Etzioni, R., Bolouri, H., Montgomery, B., White, T., et al. (2016) Substantial interindividual and limited intraindividual genomic diversity among tumors from men with metastatic prostate cancer. Nature Medicine 22 369-378.

Kumar, R., Betney, R., Li, J., Thompson, E. B. \& McEwan, I. J. (2004) Induced $\alpha$-helix structure in AF1 of the androgen receptor upon binding transcription factor TFIIF Biochemistry 43 3008-3013.

Kuriyan, J. (2004) Allostery and coupled sequence variation in nuclear hormone receptors. Cell 116 354-356.

Langley, E., Kemppainen, J. a. \& Wilson, E. M. (1998) Intermolecular NH2-/carboxyl-terminal interactions in androgen receptor dimerization revealed by mutations that cause androgen insensitivity. Journal of Biological Chemistry 273 92-101.

Langley, E., Zhou, Z.-x. \& Wilson, E. M. (1995) Evidence for an anti-parallel orientation of the ligand-activated human androgen receptor dimer. The Journal of Biological Chemistry 270 29983-29990.

Lempiäinen, J. K., Niskanen, E. A., Vuoti, K.-M., Lampinen, R. E., Göös, H., Varjosalo, M. \& Palvimo, J. J. (2017) Agonist-specific protein interactomes of glucocorticoid and androgen receptor as revealed by proximity mapping. Molecular \& Cellular Proteomics 16 1462-1474.

Li, J., Motlagh, H. N., Chakuroff, C., Thompson, E. B. \& Hilser, V. J. (2012) Thermodynamic dissection of the intrinsically disordered $\mathrm{N}$-terminal domain of human glucocorticoid receptor. Journal of Biological Chemistry 287 26777-26787.

Li, Q., Deng, Q., Chao, H.-P., Liu, X., Lu, Y., Lin, K., Liu, B., Tang, G. W., Zhang, D., Tracz, A., et al. (2018) Linking prostate cancer cell AR heterogeneity to distinct castration and enzalutamide responses. Nature Communications 9 3600-3600.

Lieberman, A. P. (2018) Spinal and bulbar muscular atrophy. Handbook of Clinical Neurology.

Liu, B., Gu, X., Huang, T., Luan, Y. \& Ding, X. (2017) Identification of TMPRSS2-ERG mechanisms in prostate cancer invasiveness: Involvement of MMP-9 and plexin B1. Oncology Reports 37 201-208.

Liu, L. L., Xie, N., Sun, S., Plymate, S., Mostaghel, E. \& Dong, X. (2014) Mechanisms of the androgen receptor splicing in prostate cancer cells. Oncogene 33 3140-3150.

Lorente, D., Mateo, J., Zafeiriou, Z., Smith, A. D., Sandhu, S., Ferraldeschi, R. \& De Bono, J. S. (2015) Switching and withdrawing hormonal agents for castration-resistant prostate cancer. Nature Reviews Urology 12 37-47.

Lou, X., Toresson, G., Benod, C., Suh, J. H., Philips, K. J., Webb, P. \& Gustafsson, J.-A. (2014) Structure of the retinoid $X$ receptor $\alpha$-liver $X$ receptor $\beta(R X R \alpha-\operatorname{LXR} \beta)$ heterodimer on DNA. Nature Structural \& Molecular Biology 21 277-281.

Love, M. I., Huska, M. R., Jurk, M., Schöpflin, R., Starick, S. R., Schwahn, K., Cooper, S. B., Yamamoto, K. R., Thomas-Chollier, M., Vingron, M., et al. (2017) Role of the chromatin landscape and sequence in determining cell type-specific genomic glucocorticoid receptor binding and gene regulation. Nucleic Acids Research 45 1805-1819. 
Lubahn, D. B., Joseph, D. R., Sullivan, P. M., Willard, H. F., French, F. S. \& Wilson, E. M. (1988) Cloning of human androgen receptor complementary DNA and localization to the $\mathrm{X}$ chromosome. Science 240 327-330.

Luisi, B. F., Xu, W. X., Otwinowski, Z., Freedman, L. P., Yamamoto, K. R. \& Sigler, P. B. (1991) Crystallographic analysis of the interaction of the glucocorticoid receptor with DNA. Nature 352 497-505.

Luo, J., Attard, G., Balk, S. P., Bevan, C., Burnstein, K., Cato, L., Cherkasov, A., De Bono, J. S., Dong, Y., Gao, A. C., et al. (2018) Role of androgen receptor variants in prostate cancer: Report from the 2017 mission androgen receptor variants meeting. European Urology 73 715723.

Mackinnon, J. A. G., Gallastegui, N., Osguthorpe, D. J., Hagler, A. T. \& Estébanez-Perpiñá, E. (2014) Allosteric mechanisms of nuclear receptors: insights from computational simulations. Molecular and Cellular Endocrinology 393 75-82.

Matias, P. M., Donner, P., Coelho, R., Thomaz, M., Peixoto, C., Macedo, S., Otto, N., Joschko, S., Scholz, P., Wegg, A., et al. (2000) Structural evidence for ligand specificity in the binding domain of the human androgen receptor: Implications for pathogenic gene mutations. Journal of Biological Chemistry 275 26164-26171.

McEwan, I. J. (2012a) Intrinsic disorder in the androgen receptor: Identification, characterisation and drugability. Molecular BioSystems 8 82-90.

McEwan, I. J. (2012b) Nuclear hormone receptors: Allosteric switches. Molecular and Cellular Endocrinology 348 345-347.

McEwan, I. J., Lavery, D., Fischer, K. \& Watt, K. (2007) Natural disordered sequences in the amino terminal domain of nuclear receptors: lessons from the androgen and glucocorticoid receptors. Nuclear receptor signaling 5 e001-e001.

Meijsing, S. H., Pufall, M. A., So, A. Y., Bates, D. L., Chen, L. \& Yamamoto, K. R. (2009) DNA binding site sequence directs glucocorticoid receptor structure and activity. Science 324 407410.

Michigami, T., Suga, A., Yamazaki, M., Shimizu, C., Cai, G., Okada, S. \& Ozono, K. (1999) Identification of amino acid sequence in the hinge region of human vitamin $\mathrm{D}$ receptor that transfers a cytosolic protein to the nucleus. The Journal of biological chemistry 274 33531-8.

Minges, J. T., Su, S., Grossman, G., Blackwelder, A. J., Pop, E. A., Mohler, J. L. \& Wilson, E. M. (2013) Melanoma antigen-a11 (MAGE-a11) enhances transcriptional activity by linking androgen receptor dimers. The Journal of Biological Chemistry 288 1939-1952.

Mohler, M. L., Coss, C. C., Duke, C. B., Patil, S. A., Miller, D. D. \& Dalton, J. T. (2012) Androgen receptor antagonists: a patent review (2008-2011). Expert Opinion on Therapeutic Patents 22 541-565.

Monaghan, A. \& McEwan, I. (2016) A sting in the tail: the N-terminal domain of the androgen receptor as a drug target. Asian Journal of Andrology 18 687-694.

Mongan, N. P., Tadokoro-Cuccaro, R., Bunch, T. \& Hughes, I. A. (2015) Androgen insensitivity syndrome. Best Practice \& Research Clinical Endocrinology \& Metabolism 29 569-580.

Moore, J. T., Collins, J. L. \& Pearce, K. H. (2006) The nuclear receptor superfamily and drug discovery. ChemMedChem 1 504-523.

Nadal, M., Prekovic, S., Gallastegui, N., Helsen, C., Abella, M., Zielinska, K., Gay, M., Vilaseca, M., TaulÃ "s, M., Houtsmuller, A. B., et al. (2017) Structure of the homodimeric androgen receptor ligand-binding domain. Nature Communications 8.

Narayanan, R., Coss, C. C. \& Dalton, J. T. (2018) Development of selective androgen receptor modulators (SARMs). Molecular and Cellular Endocrinology 465 134-142.

Narayanan, S., Srinivas, S. \& Feldman, D. (2016) Androgen-glucocorticoid interactions in the era of novel prostate cancer therapy. Nature Reviews Urology 13 47-60.

Nasrazadani, A., Thomas, R. A., Oesterreich, S. \& Lee, A. V. (2018) Precision medicine in hormone receptor-positive breast cancer. Frontiers in Oncology 8 144-144. 
Nevedomskaya, E., Baumgart, S. J. \& Haendler, B. (2018) Recent advances in prostate cancer treatment and drug discovery. International Journal of Molecular Sciences 19.

Nicolaides, N. C. \& Charmandari, E. (2015) Chrousos syndrome: from molecular pathogenesis to therapeutic management. European Journal of Clinical Investigation 45 504-514.

Nicolaides, N. C. \& Charmandari, E. (2017) Novel insights into the molecular mechanisms underlying generalized glucocorticoid resistance and hypersensitivity syndromes. Hormones 16 124-138.

Nicolaides, N. C., Galata, Z., Kino, T., Chrousos, G. P. \& Charmandari, E. (2010) The human glucocorticoid receptor: Molecular basis of biologic function. Steroids 75 1-12.

Nicolaides, N. C., Geer, E. B., Vlachakis, D., Roberts, M. L., Psarra, A.-M. G., Moutsatsou, P., Sertedaki, A., Kossida, S. \& Charmandari, E. (2015a) A novel mutation of the $h G R$ gene causing Chrousos syndrome. European Journal of Clinical Investigation 45 782-791.

Nicolaides, N. C., Lamprokostopoulou, A., Polyzos, A., Kino, T., Katsantoni, E., Triantafyllou, P., Christophoridis, A., Katzos, G., Dracopoulou, M., Sertedaki, A., et al. (2015b) Transient generalized glucocorticoid hypersensitivity. European Journal of Clinical Investigation $\mathbf{4 5}$ 1306-1315.

Nwachukwu, J. C., Srinivasan, S., Zheng, Y., Wang, S., Min, J., Dong, C., Liao, Z., Nowak, J., Wright, N. J., Houtman, R., et al. (2016) Predictive features of ligand-specific signaling through the estrogen receptor. Molecular Systems Biology 12 864-864.

Onigata, K. \& Szinnai, G. (2014) Resistance to thyroid hormone. IN SZINNAI, G. (Ed.) Paediatric Thyroidology. Karger.

Paakinaho, V., Presman, D. M., Ball, D. A., Johnson, T. A., Schiltz, R. L., Levitt, P., Mazza, D., Morisaki, T., Karpova, T. S. \& Hager, G. L. (2017) Single-molecule analysis of steroid receptor and cofactor action in living cells. Nature Communications 8 1-14.

Park, K., Dalton, J. T., Narayanan, R., Barbieri, C. E., Hancock, M. L., Bostwick, D. G., Steiner, M. S. \& Rubin, M. A. (2014) <i>TMPRSS2:ERG</i> gene fusion predicts subsequent detection of prostate cancer in patients with high-grade prostatic intraepithelial neoplasia. Journal of Clinical Oncology 32 206-211.

Paschalis, A., Sharp, A., Welti, J. C., Neeb, A., Raj, G. V., Luo, J., Plymate, S. R. \& de Bono, J. S. (2018) Alternative splicing in prostate cancer. Nature Reviews Clinical Oncology 15 663675.

Pennuto, M. \& Rinaldi, C. (2018) From gene to therapy in spinal and bulbar muscular atrophy: Are we there yet? Molecular and Cellular Endocrinology 465 113-121.

Perissi, V. \& Rosenfeld, M. G. (2005) Controlling nuclear receptors: the circular logic of cofactor cycles. Nature Reviews Molecular Cell Biology 6 542-554.

Ponnusamy, S., Coss, C. C., Thiyagarajan, T., Watts, K., Hwang, D.-J., He, Y., Selth, L. A., McEwan, I. J., Duke, C. B., Pagadala, J., et al. (2017) Novel selective agents for the degradation of androgen receptor variants to treat castration-resistant prostate cancer. Cancer Research 77 6282-6298.

Prescott, J. \& Coetzee, G. A. (2006) Molecular chaperones throughout the life cycle of the androgen receptor. Cancer Letters 231 12-19.

Presman, D. M., Ball, D. A., Paakinaho, V., Grimm, J. B., Lavis, L. D., Karpova, T. S. \& Hager, G. L. (2017) Quantifying transcription factor binding dynamics at the single-molecule level in live cells. Methods 123 76-88.

Presman, D. M., Ganguly, S., Schiltz, R. L., Johnson, T. A., Karpova, T. S. \& Hager, G. L. (2016) DNA binding triggers tetramerization of the glucocorticoid receptor in live cells. Proceedings of the National Academy of Sciences of the United States of America 113 8236-8241.

Presman, D. M. \& Hager, G. L. (2017) More than meets the dimer: What is the quaternary structure of the glucocorticoid receptor? Transcription 8 32-39.

Pritchard, C. C., Mateo, J., Walsh, M. F., De Sarkar, N., Abida, W., Beltran, H., Garofalo, A., Gulati, R., Carreira, S., Eeles, R., et al. (2016) Inherited DNA-repair gene mutations in men with metastatic prostate cancer. New England Journal of Medicine 375 443-453. 
Quigley, D. A., Dang, H. X., Zhao, S. G., Lloyd, P., Aggarwal, R., Alumkal, J. J., Foye, A., Kothari, V., Perry, M. D., Bailey, A. M., et al. (2018) Genomic hallmarks and structural variation in metastatic prostate cancer. Cell 174 758-769.e9.

Rastinejad, F., Ollendorff, V. \& Polikarpov, I. (2015) Nuclear receptor full-length architectures: confronting myth and illusion with high resolution. Trends in Biochemical Sciences $\mathbf{4 0}$ 16-24.

Ravindranathan, P., Lee, T.-K., Yang, L., Centenera, M. M., Butler, L., Tilley, W. D., Hsieh, J.-T., Ahn, J.-M. \& Raj, G. V. (2013) Peptidomimetic targeting of critical androgen receptorcoregulator interactions in prostate cancer. Nature Communications 4 1923-1923.

Reig, Ò., Marín-Aguilera, M., Carrera, G., Jiménez, N., Paré, L., García-Recio, S., Gaba, L., Pereira, M. V., Fernández, P., Prat, A., et al. (2016) TMPRSS2-ERG in blood and docetaxel resistance in metastatic castration-resistant prostate cancer. European Urology 70 709713.

Reinert, T., Gonçalves, R. \& Bines, J. (2018) Implications of ESR1 mutations in hormone receptorpositive breast cancer. Current Treatment Options in Oncology 19 24-24.

Robertson, S., Hapgood, J. P. \& Louw, A. (2013a) Glucocorticoid receptor concentration and the ability to dimerize influence nuclear translocation and distribution. Steroids 78 182-194.

Robertson, S., Rohwer, J. M., Hapgood, J. P. \& Louw, A. (2013b) Impact of glucocorticoid receptor density on ligand-independent dimerization, cooperative ligand-binding and basal priming of transactivation: A cell culture model. PLOS ONE 8 e64831-e64831.

Robinson, D., Van Allen, Eliezer M., Wu, Y.-M., Schultz, N., Lonigro, Robert J., Mosquera, J.-M., Montgomery, B., Taplin, M.-E., Pritchard, Colin C., Attard, G., et al. (2015) Integrative clinical genomics of advanced prostate cancer. Cell 161 1215-1228.

Rodrigues, L. U., Rider, L., Nieto, C., Romero, L., Karimpour-Fard, A., Loda, M., Lucia, M. S., Wu, M., Shi, L., Cimic, A., et al. (2015) Coordinate loss of MAP3K7 and CHD1 promotes aggressive prostate cancer. Cancer Research 75 1021-1034.

Ruggero, K., Farran-Matas, S., Martinez-Tebar, A. \& Aytes, A. (2018) Epigenetic regulation in prostate cancer progression. Current Molecular Biology Reports 4 101-115.

Sack, J. S., Kish, K. F., Wang, C., Attar, R. M., Kiefer, S. E., An, Y., Wu, G. Y., Scheffler, J. E., Salvati, M. E., Krystek, S. R., et al. (2001) Crystallographic structures of the ligand-binding domains of the androgen receptor and its T877A mutant complexed with the natural agonist dihydrotestosterone. Proceedings of the National Academy of Sciences 98 49044909.

Sadar, M. D. (2011) Small molecule inhibitors targeting the "Achilles' heel" of androgen receptor activity. Cancer Research 71 1208-1213.

Schaufele, F., Carbonell, X., Guerbadot, M., Borngraeber, S., Chapman, M. S., Ma, A. A. K., Miner, J. N. \& Diamond, M. I. (2005) The structural basis of androgen receptor activation: Intramolecular and intermolecular amino-carboxy interactions. Proceedings of the National Academy of Sciences 102 9802-9807.

Schöne, S., Jurk, M., Helabad, M. B., Dror, I., Lebars, I., Kieffer, B., Imhof, P., Rohs, R., Vingron, M., Thomas-Chollier, M., et al. (2016) Sequences flanking the core-binding site modulate glucocorticoid receptor structure and activity. Nature Communications 712621.

Schrecengost, R. \& Knudsen, K. E. (2013) Molecular pathogenesis and progression of prostate cancer. Seminars in Oncology 40 244-258.

Schwabe, J. W., Chapman, L., Finch, J. T. \& Rhodes, D. (1993) The crystal structure of the estrogen-receptor DNA-binding domain bound to DNA - how receptors discriminate between their response elements. Cell 75 567-576.

Shaffer, P. L., Jivan, A., Dollins, D. E., Claessens, F. \& Gewirth, D. T. (2004) Structural basis of androgen receptor binding to selective androgen response elements. Proceedings of the National Academy of Sciences of the United States of America 101 4758-4763.

Shen, M. M. \& Abate-Shen, C. (2010) Molecular genetics of prostate cancer: new prospects for old challenges. Genes \& Development 24 1967-2000. 
Spada, A. R. L., Wilson, E. M., Lubahn, D. B., Harding, A. E. \& Fischbeck, K. H. (1991) Androgen receptor gene mutations in X-linked spinal and bulbar muscular atrophy. Nature 352 7779.

Srinivasan, S., Nwachukwu, J. C., Parent, A. A., Cavett, V., Nowak, J., Hughes, T. S., Kojetin, D. J., Katzenellenbogen, J. A. \& Nettles, K. W. (2013) Ligand-binding dynamics rewire cellular signaling via estrogen receptor- $\alpha$. Nature Chemical Biology 9 326-332.

Stelloo, S., Nevedomskaya, E., Kim, Y., Schuurman, K., Valle-Encinas, E., Lobo, J., Krijgsman, O., Peeper, D. S., Chang, S. L., Feng, F. Y.-C., et al. (2018) Integrative epigenetic taxonomy of primary prostate cancer. Nature Communications 9 4900-4900.

Sung, M. H., Guertin, M. J., Baek, S. \& Hager, G. L. (2014) DNase footprint signatures are dictated by factor dynamics and DNA sequence. Molecular Cell 56 275-285.

Swinstead, E. E., Miranda, T. B., Paakinaho, V., Baek, S., Goldstein, I., Hawkins, M., Karpova, T. S., Ball, D., Mazza, D., Lavis, L. D., et al. (2016) Steroid receptors reprogram FoxA1 occupancy through dynamic chromatin transitions. Cell 165 593-605.

Takeda, D. Y., Spisák, S. n., Seo, J. H., Bell, C., O'Connor, E., Korthauer, K., Ribli, D., Csabai, I., Solymosi, N., Szállási, Z., et al. (2018) A somatically acquired enhancer of the androgen receptor is a noncoding driver in advanced prostate cancer. Cell 422-432.

Tien, A. H. \& Sadar, M. D. (2018) Order within a disordered structure. Structure 26 4-6.

Treviño, L. S. \& Weigel, N. L. (2013) Phosphorylation: A fundamental regulator of steroid receptor action. Trends in Endocrinology and Metabolism 24 515-524.

Uo, T., Plymate, S. R. \& Sprenger, C. C. (2017) Allosteric alterations in the androgen receptor and activity in prostate cancer. Endocrine-Related Cancer 24 R335-R348.

van der Steen, T., Tindall, D. J. \& Huang, H. (2013) Posttranslational modification of the androgen receptor in prostate cancer. International Journal of Molecular Sciences 14 1483314859.

van Royen, M. E., van Cappellen, W. A., de Vos, C., Houtsmuller, A. B. \& Trapman, J. (2012) Stepwise androgen receptor dimerization. Journal of Cell Science 125 1970-1979.

Veras Ribeiro Filho, H., Tambones, I. L., Mariano Gonçalves Dias, M., Bernardi Videira, N., Bruder, M., Amorim Amato, A. \& Migliorini Figueira, A. C. (2019) Modulation of nuclear receptor function: Targeting the protein-DNA interface. Molecular and Cellular Endocrinology 484 1-14.

Viswanathan, S. R., Ha, G., Hoff, A. M., Wala, J. A., Carrot-Zhang, J., Whelan, C. W., Haradhvala, N. J., Freeman, S. S., Reed, S. C., Rhoades, J., et al. (2018) Structural alterations driving castration-resistant prostate cancer revealed by linked-read genome sequencing. Cell 174 433-447.e19.

Vitellius, G., Fagart, J., Delemer, B., Amazit, L., Ramos, N., Bouligand, J., Le Billan, F., Castinetti, F., Guiochon-Mantel, A., Trabado, S., et al. (2016) Three novel heterozygous point mutations of NR3C1 causing glucocorticoid resistance. Human Mutation 37 794-803.

Vitellius, G., Trabado, S., Hoeffel, C., Bouligand, J., Bennet, A., Castinetti, F., Decoudier, B., Guiochon-Mantel, A., Lombes, M., Delemer, B., et al. (2018) Significant prevalence of NR3C1 mutations in incidentally discovered bilateral adrenal hyperplasia: results of the French MUTA-GR Study. European Journal of Endocrinology 178 411-423.

Voss, T. C., Schiltz, R. L., Sung, M. H., Yen, P. M., Stamatoyannopoulos, J. A., Biddie, S. C., Johnson, T. A., Miranda, T. B., John, S. \& Hager, G. L. (2011) Dynamic exchange at regulatory elements during chromatin remodeling underlies assisted loading mechanism. Cell 146 544-554.

Wang, L., Lonard, D. M. \& O'Malley, B. W. (2016) The role of steroid receptor coactivators in hormone dependent cancers and their potential as therapeutic targets. Hormones and Cancer $7229-235$.

Watson, P. A., Arora, V. K. \& Sawyers, C. L. (2015) Emerging mechanisms of resistance to androgen receptor inhibitors in prostate cancer. Nature Reviews Cancer 15 701-711. 
Wedge, D. C., Gundem, G., Mitchell, T., Woodcock, D. J., Martincorena, I., Ghori, M., Zamora, J., Butler, A., Whitaker, H., Kote-Jarai, Z., et al. (2018) Sequencing of prostate cancers identifies new cancer genes, routes of progression and drug targets. Nature Genetics $\mathbf{5 0}$ 682-692.

Weikum, E. R., Knuesel, M. T., Ortlund, E. A. \& Yamamoto, K. R. (2017) Glucocorticoid receptor control of transcription: Precision and plasticity via allostery. Nature Reviews Molecular Cell Biology 18 159-174.

Weikum, E. R., Liu, X. \& Ortlund, E. A. (2018) The nuclear receptor superfamily: A structural perspective. Protein Science 27 1876-1892.

Weiss, R. E., Marcocci, C., Bruno-Bossio, G. \& Refetoff, S. (1993) Multiple genetic factors in the heterogeneity of thyroid hormone resistance. The Journal of Clinical Endocrinology \& Metabolism 76 257-259.

Wilkinson, L., Verhoog, N. J. D. \& Louw, A. (2018) Disease- and treatment-associated acquired glucocorticoid resistance. Endocrine Connections 12 R328-R349.

Wu, Y.-M., Cieslik, M., Lonigro, R. J., Vats, P., Reimers, M. A., Cao, X., Ning, Y., Wang, L., Kunju, L. P., de Sarkar, N., et al. (2018) Inactivation of CDK12 delineates a distinct immunogenic class of advanced prostate cancer. Cell 173 1770-1782.e14.

Wurtz, J.-M., Bourguet, W., Renaud, J.-P., Vivat, V. r., Chambon, P., Moras, D. \& Gronemeyer, H. (1996) A canonical structure for the ligand-binding domain of nuclear receptors. Nature Structural Biology 3 87-94.

Yi, P., Wang, Z., Feng, Q., Pintilie, Grigore D., Foulds, Charles E., Lanz, Rainer B., Ludtke, Steven J., Schmid, Michael F., Chiu, W. \& O'Malley, Bert W. (2015) Structure of a biologically active estrogen receptor-coactivator complex on DNA. Molecular Cell 57 1047-1058.

Yu, J., Yu, J., Mani, R.-S., Cao, Q., Brenner, C. J., Cao, X., Wang, X., Wu, L., Li, J., Hu, M., et al. (2010) An integrated network of androgen receptor, Polycomb, and TMPRSS2-ERG gene fusions in prostate cancer progression. Cancer Cell 17 443-454.

Zennaro, M.-C. \& Fernandes-Rosa, F. (2017) 30 years of the mineralocorticoid receptor: Mineralocorticoid receptor mutations. Journal of Endocrinology 234 T93-T106.

Zhao, D., Lu, X., Wang, G., Lan, Z., Liao, W., Li, J., Liang, X., Chen, J. R., Shah, S., Shang, X., et al. (2017) Synthetic essentiality of chromatin remodelling factor CHD1 in PTEN-deficient cancer. Nature 542 484-488.

Zoubeidi, A., Zardan, A., Beraldi, E., Fazli, L., Sowery, R., Rennie, P., Nelson, C. \& Gleave, M. E. (2007) Cooperative interactions between androgen receptor (AR) and heat-shock protein 27 facilitate AR transcriptional activity. Cancer Research 67 10455-10465. 
NTD

DBD

LBD
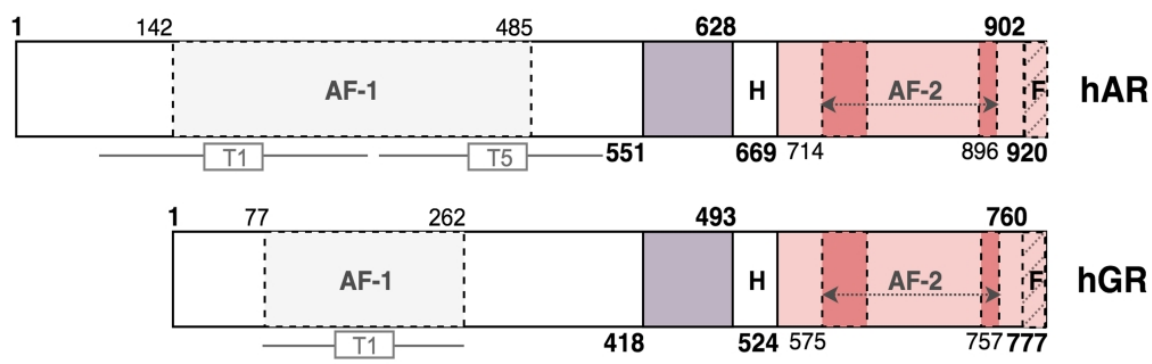

hGR

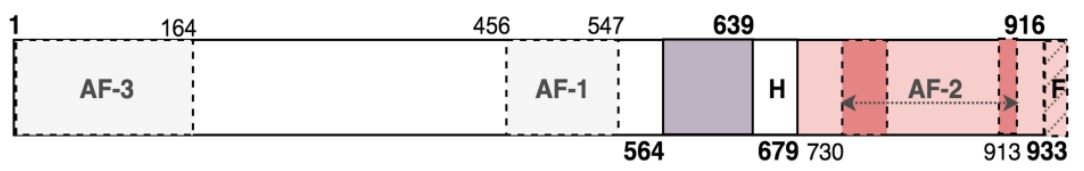

hPR
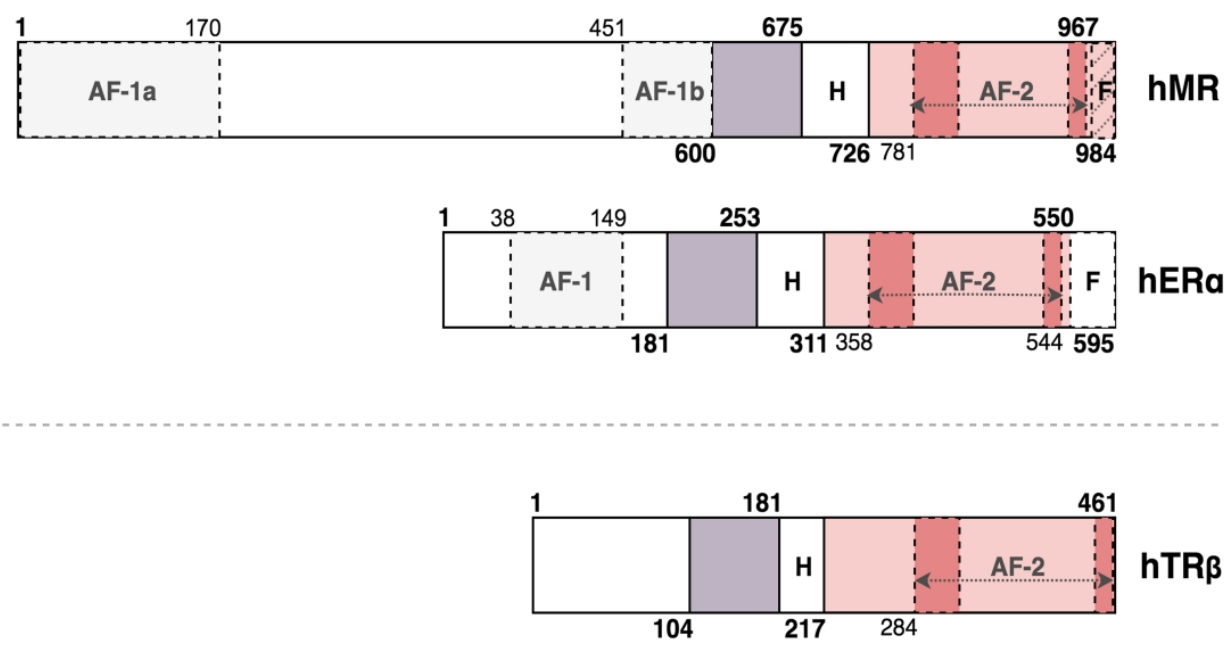

Figure 1 
A

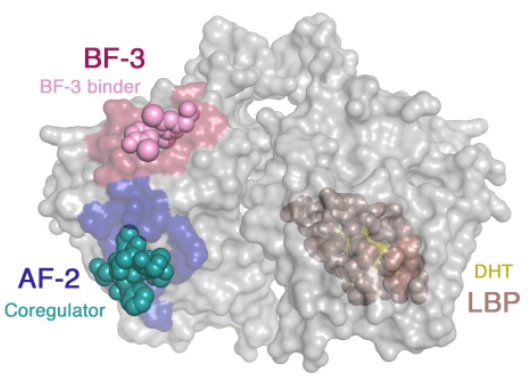

B

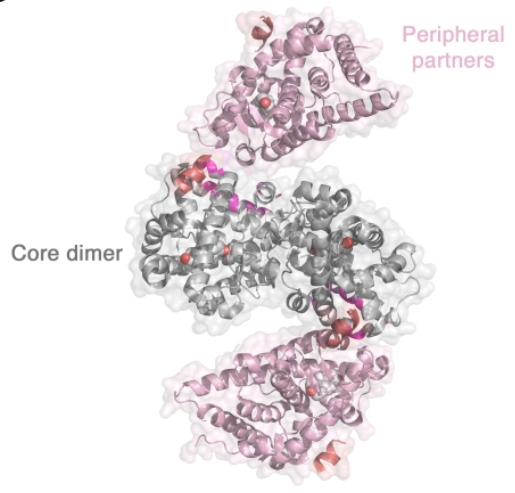

Figure 2 
A

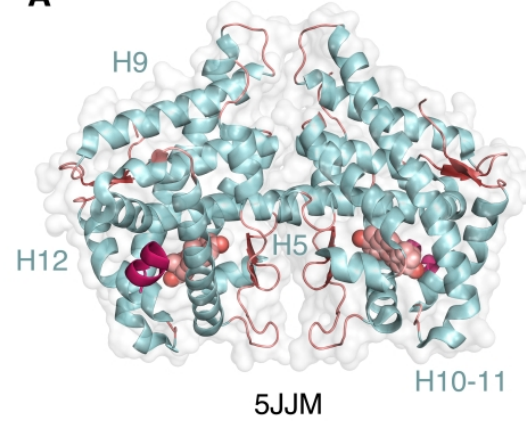

C

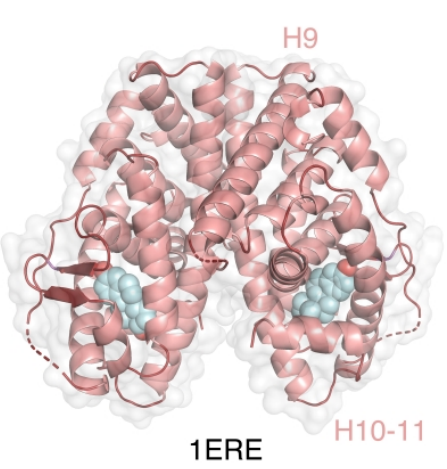

B

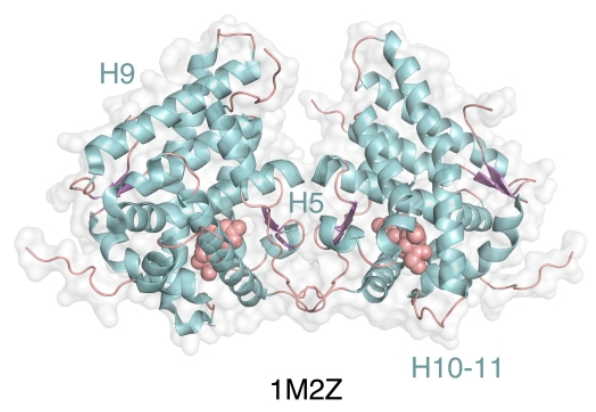

D

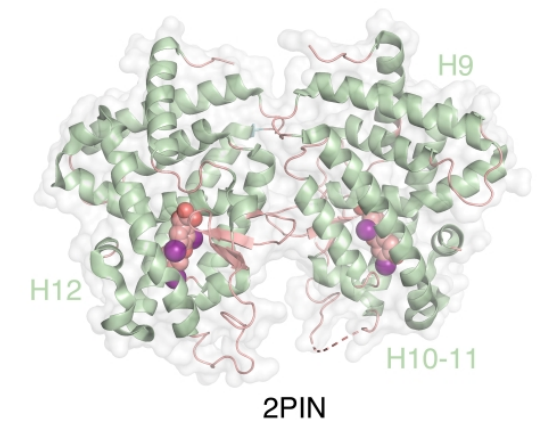

Figure 3 
A

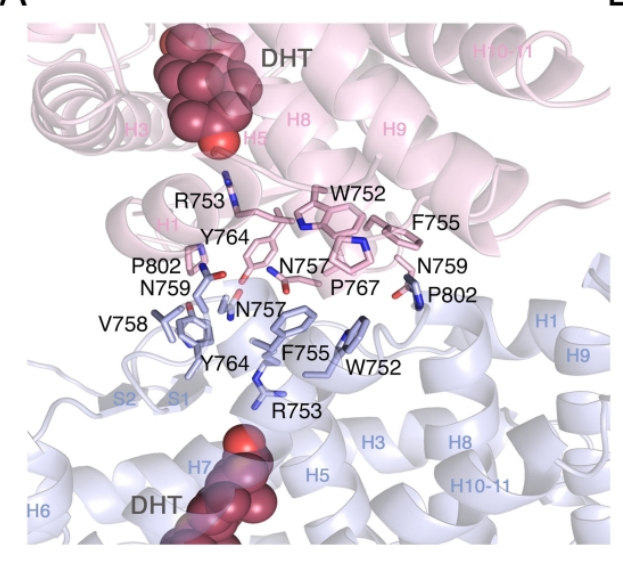

B

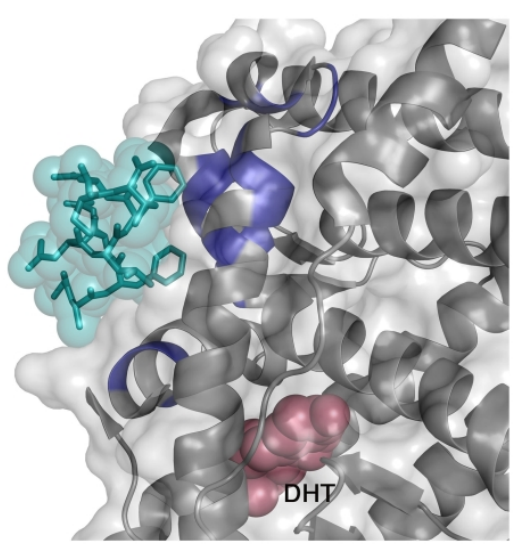

Figure 4

$149 \times 75 \mathrm{~mm}(600 \times 600 \mathrm{DPI})$ 
A

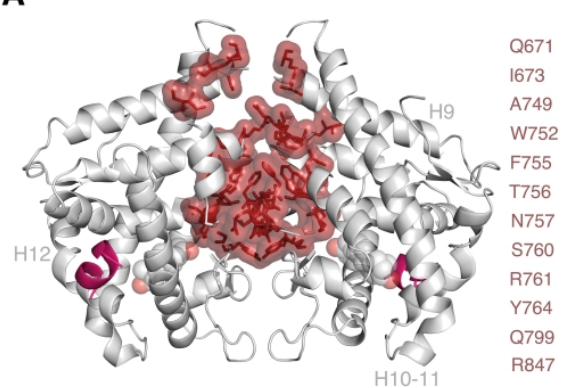

B

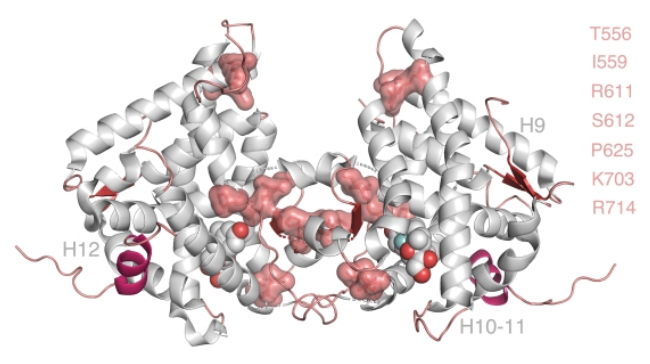

D

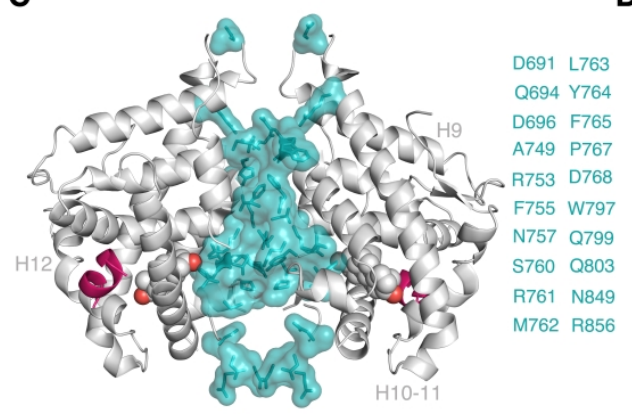

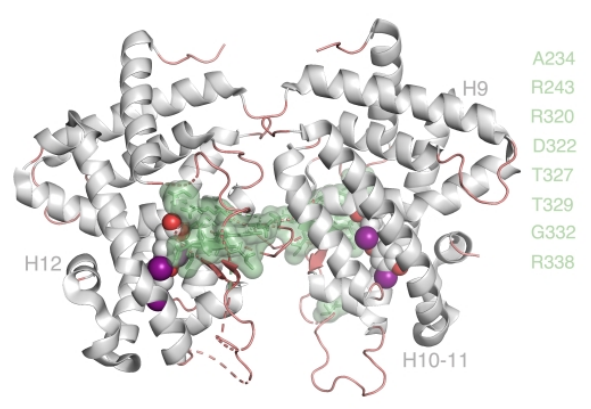

Figure 5 


\begin{tabular}{|c|c|c|c|c|c|c|c|}
\hline \multicolumn{2}{|c|}{$\begin{array}{l}\text { ANDROGEN } \\
\text { RECEPTOR }\end{array}$} & \multicolumn{2}{|c|}{$\begin{array}{l}\text { GLUCOCORTICOID } \\
\text { RECEPTOR }\end{array}$} & \multicolumn{2}{|c|}{$\begin{array}{l}\text { ESTROGEN } \\
\text { RECEPTOR }\end{array}$} & \multicolumn{2}{|c|}{ THYROID RECEPTOR } \\
\hline Residue & Disease & Residue & Disease & Residue & Disease & Residue & Disease \\
\hline Q671R & $\mathrm{PCa}$ & & & & & & \\
\hline I673T & PCa & & & & & & \\
\hline V685I & CAIS & V543 & & 1326 & & A234T & $\begin{array}{l}\text { THR (Behr } \\
\text { and Loos } \\
\text { 1992) }\end{array}$ \\
\hline C687R & PAIS & Y545 & & Y328 & & $\begin{array}{l}R 243 Q \\
R 243 W\end{array}$ & $\begin{array}{l}\text { THR (J } \\
\text { Pohlenz et } \\
\text { al. } \\
\text { 1996),(Yagi } \\
\text { et al. 1997) }\end{array}$ \\
\hline $\begin{array}{l}\text { D691E } \\
\text { D691V }\end{array}$ & $\begin{array}{l}\text { PAIS } \\
\text { CAIS }\end{array}$ & D549 & & $\mathrm{X}$ & & K244 & \\
\hline $\begin{array}{l}\text { D696H } \\
\text { D696N } \\
\text { D696V } \\
\text { D696Y }\end{array}$ & $\begin{array}{l}\text { CAIS } \\
\text { CAIS/PAIS/ } \\
\text { M } \\
\text { CAIS } \\
\text { CAIS }\end{array}$ & D554 & & F337 & & $\begin{array}{l}1250 \\
1250 T\end{array}$ & $\begin{array}{l}\text { THR (Asadi } \\
\text { et al. 2008) }\end{array}$ \\
\hline $\begin{array}{l}\text { A749T } \\
\text { A749D }\end{array}$ & $\begin{array}{l}\text { PCa } \\
\text { PAIS }\end{array}$ & & & & & & \\
\hline W752R & $\mathrm{PCa}$ & W610 & & W393 & & V319 & \\
\hline $\begin{array}{l}\text { R753P } \\
\text { R753Q }\end{array}$ & $\begin{array}{l}\text { CAIS } \\
\text { CAIS }\end{array}$ & R611L & $\begin{array}{l}\text { GCR } \\
\text { (Schmidt } \\
\text { et al. } \\
\text { 2006) }\end{array}$ & $\mathrm{R} 394 \mathrm{H}$ & $\begin{array}{l}\text { Estrogen } \\
\text { insensitivi } \\
\text { ty } \\
\text { (Bernard } \\
\text { et al. } \\
2017 \text { ) }\end{array}$ & $\begin{array}{l}\mathrm{R} 320 \mathrm{C} \\
\mathrm{R} 32 \mathrm{OH}\end{array}$ & $\begin{array}{l}\text { THR } \\
\text { (Weiss, } \\
\text { Weinberg, } \\
\text { and } \\
\text { Refetoff } \\
\text { 1993) } \\
\text { (Cugini et } \\
\text { al. 1992) }\end{array}$ \\
\hline $\begin{array}{l}\text { F755L } \\
\text { F755S } \\
\text { F755V }\end{array}$ & $\begin{array}{l}\mathrm{PCa} \\
\text { PAIS/MAIS } \\
\text { CAIS }\end{array}$ & Y613 & & M396 & & D322H & $\begin{array}{l}\text { THR } \\
\text { (Cheng et } \\
\text { al. 1994) }\end{array}$ \\
\hline T756A & $\mathrm{PCa}$ & R614 & & E397 & & L328S & $\begin{array}{l}\text { THR } \\
\text { (Grace, } \\
\text { Buzard, } \\
\text { and } \\
\text { Weintraub } \\
\text { 1995) }\end{array}$ \\
\hline $\begin{array}{l}\text { N757D } \\
\text { N757S }\end{array}$ & $\begin{array}{l}\text { PCa } \\
\text { PAIS/MAIS }\end{array}$ & Q615 & & $x$ & & E324 & \\
\hline $\begin{array}{l}\text { S760F } \\
\text { S760P } \\
\text { S760Y }\end{array}$ & $\begin{array}{l}\text { CAIS } \\
\text { PCa } \\
\text { CAIS }\end{array}$ & A618 & & H398 & & P323 & \\
\hline $\begin{array}{l}\text { R761? } \\
\text { R761S }\end{array}$ & $\begin{array}{l}\text { PCa } \\
\text { PAIS }\end{array}$ & N619 & & G400 & & $\begin{array}{l}\text { P323/D } \\
324\end{array}$ & \\
\hline M762T & PAIS & L620 & & K401 & & E326 & \\
\hline L763F & CAIS & L621 & & L402 & & $\begin{array}{l}\text { T327P } \\
\text { T327A }\end{array}$ & $\begin{array}{l}\text { THR (Borck } \\
\text { et al. 2009) }\end{array}$ \\
\hline
\end{tabular}




\begin{tabular}{|c|c|c|c|c|c|c|c|}
\hline & & & & & & & $\begin{array}{l}\text { (Asadi et } \\
\text { al. 2008) }\end{array}$ \\
\hline $\begin{array}{l}\text { Y764C } \\
\text { Y764H }\end{array}$ & $\begin{array}{l}\mathrm{PCa} / \mathrm{PAIS} \\
\text { CAIS }\end{array}$ & C622 & & L403 & & $\begin{array}{l}\text { T329N } \\
\text { T329I }\end{array}$ & $\begin{array}{l}\text { THR } \\
\text { (Sarkissian } \\
\text { et al. 1999) } \\
\text { (P. and J. } \\
\text { 2013) }\end{array}$ \\
\hline F765L & CAIS & F623 & & F404 & & L330S & $\begin{array}{l}\text { THR } \\
\text { (Pohlenz } \\
\text { 1997) }\end{array}$ \\
\hline $\begin{array}{l}\text { P767A } \\
\text { P767S }\end{array}$ & $\begin{array}{l}\text { CAIS } \\
\text { CAIS }\end{array}$ & P625 & $\begin{array}{l}\text { (Bledsoe } \\
\text { et al. } \\
2002 \text { ) }\end{array}$ & P406 & & $\begin{array}{l}\text { G332R } \\
\text { G332E }\end{array}$ & $\begin{array}{l}\text { THR } \\
\text { (Parrilla et } \\
\text { al. 1991) } \\
\text { (Adams et } \\
\text { al. 1994) }\end{array}$ \\
\hline $\begin{array}{l}\text { D768E } \\
\text { D768Y }\end{array}$ & $\begin{array}{l}\text { CAIS } \\
\text { CAIS }\end{array}$ & N626 & & N407 & & E333D & $\begin{array}{l}\text { THR } \\
\text { (Maraninc } \\
\text { hi et al. } \\
\text { 2006) }\end{array}$ \\
\hline E773 & & E631 & & R412 & & $\begin{array}{l}\text { R338W } \\
\text { R338L }\end{array}$ & $\begin{array}{l}\text { THR } \\
\text { (Sasaki, S } \\
\text { et al 1995) } \\
\text { THR } \\
\text { (Menzaghi } \\
\text { et al 1999) }\end{array}$ \\
\hline $\begin{array}{l}\text { W797de } \\
\text { I }\end{array}$ & CAIS & H655 & & R437 & & S362 & \\
\hline Q799E & $\begin{array}{l}\text { PCa/PAIS/ } \\
\text { M }\end{array}$ & Q657 & & N439 & & N364 & \\
\hline Q803R & PAIS & E661 & & E443 & & T368 & \\
\hline R847G & $\mathrm{PCa}$ & E705 & & G494 & & $x$ & \\
\hline N849K & CAIS & & & T496 & & $\mathrm{H} 210$ & \\
\hline $\begin{array}{l}\text { R856C } \\
\text { R856H }\end{array}$ & $\begin{array}{l}\text { CAIS } \\
\text { CAIS/PAIS/ } \\
M\end{array}$ & R714Q & $\begin{array}{l}\text { Chrousos } \\
\text { Syndrome } \\
\text { (Nader et } \\
\text { al. 2010) }\end{array}$ & R503W & $\begin{array}{l}\text { BCa } \\
\text { (Jeselsoh } \\
\text { n et al. } \\
2014 \text { ) }\end{array}$ & & \\
\hline
\end{tabular}

GCR= Glucocorticoid resistance

THR= Thyroid hormone resistance 